\title{
Prospects for the treatment of endocrine-responsive tumours
}

\author{
$S$ Green and B Furr \\ Therapeutic Research Department, Zeneca Pharmaceuticals, Alderley Park, Macclesfield, Cheshire, SK10 \\ 4TG, UK \\ (Requests for offprints should be addressed to S Green; Email: stephen.green@alderley.zeneca.com)
}

\begin{abstract}
Much has been achieved over the last 30 years to improve the treatment of hormone-dependent cancer of the breast, ovary and prostate. The development of the antioestrogen tamoxifen (Nolvadex) spearheaded a range of drugs that counter the growth-promoting action of the female and male sex steroid hormones. An important additional benefit of endocrine therapies has been their low toxicity compared with conventional cancer chemotherapy thereby providing effective treatment with few serious side-effects and a sustained quality of life. Although some currently available therapies improve patient disease-free survival and overall survival, particularly when given in an adjuvant setting, they are not cures. There is, therefore, a continued need to develop newer therapies that extend the effectiveness of those currently available. This is particularly important when tumours either fail to respond or develop resistance to endocrine therapy. In this review, we examine how our improved understanding of the factors that influence the progression of endocrine-related tumours is leading to the development of novel therapies to treat both hormone-dependent and -independent tumours.
\end{abstract}

Endocrine-Related Cancer (1999) 6 349-371

\section{The success of endocrine therapies}

\section{Antioestrogens}

Although the adverse effect of oestrogens on breast cancer progression was recognised at the end of the last century, it was only 30 years ago that a low molecular weight oestrogen antagonist was identified and subsequently developed successfully for the treatment of breast cancer (Harper \& Walpole 1966). The availability of pharmaceutical agents which were later shown to achieve the same clinical benefit as oophorectomy was a revolution in the management of hormone-dependent breast cancer. More recently, the identification of the breast cancer susceptibility genes BRCA1 and BRCA2 has increased our awareness of high-risk groups and led to a greater prevalence in the use of diagnostic tests to predict the risk of developing breast cancer. This has understandably produced greater pressure from women's health groups to extend the use of pharmaceutical agents into preventative medicine in order to avoid traumatic preventative surgery such as a double mastectomy.

Much has been learnt since the early 1960s about the nature of the oestrogen receptor (ER) and the molecular mechanism by which it regulates gene expression but mysteries still remain. For example, it is still unclear which oestrogen-regulated factors are critical in promoting the growth of breast cancer epithelial cells. Tamoxifen was developed as a non-steroidal, orally active antioestrogen, initially as a contraceptive agent, but was recognised as having potential benefit to treat hormoneresponsive breast cancer patients (Harper \& Walpole 1966). Antioestrogens act by competing with $17 \beta$ oestradiol for binding to a site within the ER ligandbinding domain (Fig. 1). Whereas the binding of oestradiol alters the conformation of the ligand-binding domain to promote the interaction with other transcription factors, the binding of antioestrogen prevents the formation of the active conformation (Brzozowski et al. 1997, White \& Parker 1998). It has become fashionable to describe partial agonists, such as tamoxifen and raloxifene, as SERMs (selective estrogen receptor modulators) since it is felt that this better describes their antagonist effect in some target tissues, such as the breast, and agonist effect in others, such as bone (Grese \& Dodge 1998). One possible explanation as to why tamoxifen is a partial agonist is that the drug inactivates only one of the two regions within the ER responsible for the activation of gene transcription (Green \& Chambon 1988, McInerney et al. 1998). Furthermore, non-classical oestrogen response elements have been identified, termed raloxifene response ele- 


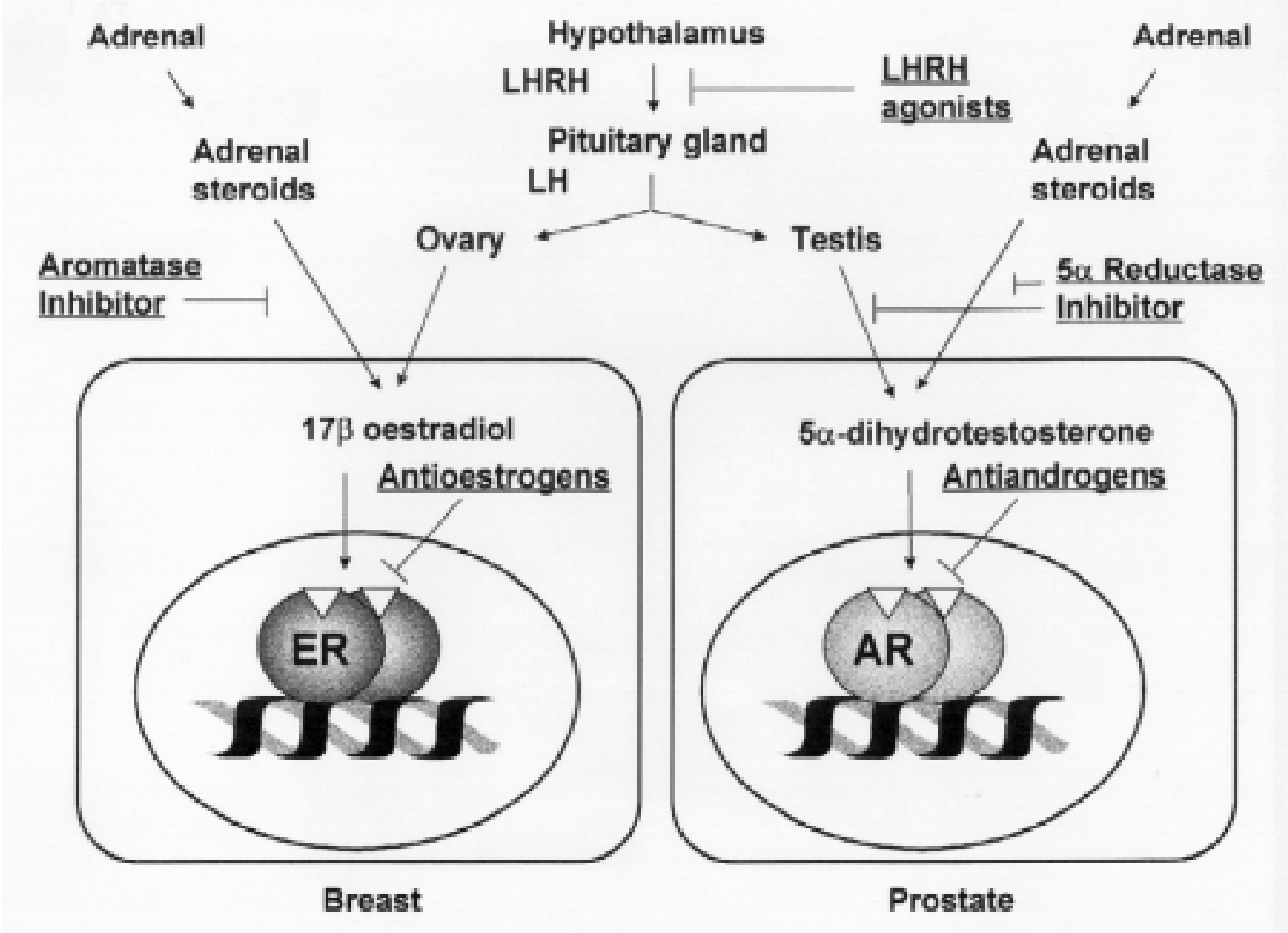

Figure 1 Endocrine therapy. Oestrogens and androgens are important mitogens promoting the growth of hormone-dependent breast and prostate cancer respectively. Total oestrogen blockade is achieved by the combination of an LHRH agonist to suppress the release of $\mathrm{LH}$, an aromatase inhibitor to suppress the production of oestrogens in post-menopausal patients and an antioestrogen to antagonise the action of oestrogens on the receptor. Total androgen blockade is achieved by the combination of an LHRH agonist and an antiandrogen.

$\mathrm{AR}$, androgen receptor.

ments, in the promoters of genes that are the targets of the agonist effect of SERMs in bone (Yang et al. 1996). The picture is even further complicated by the discovery of a second oestrogen receptor $(\mathrm{ER} \beta)$ and the finding that tamoxifen, raloxifene and the pure anti-oestrogen ICI 164,384 are pure antagonists of ER $\beta$ when measured using classical oestrogen response elements (Barkhem et al. 1998, McInerney et al. 1998). Despite the complexity of selectively modulating ER activity, a number of tamoxifen-derived SERMs, such as arzoxifene (LY 353,381), droloxifene, toremifene and idoxifene are being developed. Some of these have been used to treat osteoporosis in post-menopausal women, but increasingly are being considered as alternatives to tamoxifen for the treatment of breast cancer. The hope is that such alternatives will be as effective as tamoxifen in treating breast cancer but with a reduced risk of developing endometrial cancer. Clinical trials, such as STAR (Study of Tamoxifen and Raloxifene), are being planned that are specifically designed to establish the efficacy and safety of alternative SERMs to treat patients with breast cancer.

Extensive clinical use has demonstrated tamoxifen to be a well-tolerated and effective agent producing an objective response in approximately a third of unselected treated patients with advanced breast cancer, and disease stabilisation in a further $20 \%$ (Baum 1997). In the adjuvant setting, tamoxifen is currently the endocrine therapy of choice, irrespective of age or menopausal status, with increasing benefit observed as the length of treatment is increased to at least 5 years (Early Breast Cancer Trialists' Collaborative Group 1998). Because the action of antioestrogens is mediated by the ER, it is not surprising 
that ER-positive tumours are most responsive to therapy (Bezwoda et al. 1991), although a small rate of response is seen in apparently ER-negative tumours. As the risks and benefits of treatment with tamoxifen have become established, the use of the drug has now been extended beyond the adjuvant setting to include prophylactic use in healthy women who are considered to be at risk of developing breast cancer. The results of these prevention studies have been controversial, with the National Surgical Adjuvant Breast and Bowel Project trial in the USA being stopped early because of clear evidence of a benefit with tamoxifen treatment (Fisher et al. 1998) whilst other smaller studies have failed so far to demonstrate a significant benefit (Powles et al. 1998, Veronesi et al. 1998). It is likely that differences in the selection of patients and definition of 'high' risk contribute to this apparent discrepancy. Further studies are required to establish whether patients who are genetically predisposed to developing breast cancer will also benefit from the early use of tamoxifen.

Eventually, many patients with primary breast cancer treated with tamoxifen will relapse (Rutqvist 1998). The reasons why tumours develop resistance to tamoxifen are unknown but may be related to the partial agonist action of tamoxifen-stimulating growth. Alternatively, it is possible that genetic or epigenetic changes within the tumour activate hormone-independent mitogenic pathways; for example it has been observed that c-erbB2 is expressed in a greater proportion of patients who relapsed early (Houston et al. 1999). Support for the first proposal, that with time tamoxifen can begin to stimulate the growth of tumours, comes from both pre-clinical and clinical studies using pure antioestrogens such as ICI 182,780 (Faslodex) and EM-800 (England \& Jordan 1997). In a small phase II study $(n=19)$ with ICI 182,780, approximately two thirds of the patients who relapsed on tamoxifen therapy responded to treatment with the pure antioestrogen with a median duration of response of 26 months (Howell et al. 1996). Interestingly, it has been demonstrated in model systems that additional mitogenic signal transduction pathways are able to cross-talk with the oestrogen receptor. In one example, activation of the epidermal growth factor receptor (EGFR) stimulates the MAP kinase signalling pathway that leads to ER phosphorylation and activation even in the absence of oestrogen (Kato et al. 1995, Bunone et al. 1996). Importantly, the same authors demonstrate that pure antioestrogens such as ICI 182,780, but not tamoxifen, block growth factor-induced ER activity.

A second more recent example is the activation of ER by cyclin D1 in the absence of oestrogen (Neuman et al. 1997, Zwijsen et al. 1997). Cyclin D1 is overexpressed in approximately half of breast cancer cases (see cell cycle inhibition below), suggesting that the elevation of this G1 phase cyclin may stimulate breast cancer growth through the ER, in addition to its more classical role as an activator of cyclin-dependent kinases (CDK). Notably, the expression of cyclin D1 potentiates the effect of oestrogens (Zwijsen et al. 1997). Studies employing oestrogen-responsive reporter genes suggest that tamoxifen and pure anti-oestrogens can completely (Neuman et al. 1997) or partially (Zwijsen et al. 1997) block the ligand-independent action of cyclin D1. Furthermore, studies in cells engineered to overexpress cyclin D1 indicate that antioestrogens can inhibit the growth of these cells (Pacilio et al. 1998). These studies therefore suggest that the increased expression of cyclin D1 is unlikely to account for the development of resistance to tamoxifen although it is conceivable that high cyclin D1 levels could reduce the effect of tamoxifen.

Other recent studies have shown that aspartate 351 within the ER ligand-binding domain makes a critical contact with the side chain of the antioestrogen raloxifene (Brzozowski et al. 1997). Intriguingly, the mutation of residue 351 to tyrosine breaks the key interaction with raloxifene and converts this antagonist into an agonist (Levenson \& Jordan 1998). One interpretation of these studies is that antioestrogens, such as raloxifene and tamoxifen, use the interaction with aspartate 351 to prevent the transcriptional activation region (AF2) within the ER ligand-binding domain from adopting a conformation where it can bind to additional co-activator transcription factors. Therefore, it is possible that ER mutations that affect aspartate 351 directly, or influence the conformation of AF2, could be selected for in the tumours of relapsed patients, although no such mutations have been identified to date.

An alternative epigenetic mechanism to explain the conversion of tamoxifen-sensitive tumours to resistance is that there is an increase in the concentration of ER coactivators that stabilise the ER in the active conformation (Levenson \& Jordan 1998). Importantly, the activity of the pure antioestrogen ICI 182,780 appears to be independent of aspartate 351 (Levenson \& Jordan 1998), possibly because the bulky alkyl side chain of ICI 182,780 prevents the ER adopting the active conformation or because this drug can prevent ER dimerisation and/or promote ER degradation (White \& Parker 1998). This distinct mechanism of action may explain why ICI 182,780 is effective in producing a response in patients who have relapsed on tamoxifen and could provide an advantage over other antioestrogens (such as raloxifene) that are dependent upon maintaining the ER ligand-binding domain in the inactive conformation.

\section{Antiprogestins}

One of the actions of oestrogens is to increase the level of the progesterone receptors (PR) and the presence of 
receptors for both steroid hormones in a breast tumour predicts a high response rate to endocrine therapy (McGuire 1978). Although the co-expression of both receptors is thought simply to indicate that the ER is functional, antiprogestins, such as mifepristone (RU-486), inhibit the growth of breast cancer cell lines in vitro (Bardon et al. 1985) suggesting a direct role for the PR in promoting the growth of breast cancer. In vivo studies, utilising oestrogen-primed MCF-7 xenografts in nude mice, have demonstrated that monotherapy with tamoxifen, mifepristone or an alternative antiprogestin onapristone, reduces tumour growth (El Etreby \& Liang 1998). Furthermore, the combination of tamoxifen with mifepristone prevented tumour growth and delayed or prevented tumour escape. These studies suggest that such agents may be beneficial in treating breast cancer patients.

Mifepristone and onapristone have been evaluated in the clinic as first line therapy for primary breast cancer (Perrault et al. 1996, Robertson et al. 1999). Partial responses were observed in $10.7 \%$ of PR-positive breast cancer patients who had received no prior therapy when treated with $200 \mathrm{mg}$ mifepristone daily (Perrault et al. 1996). Better responses have been observed with onapristone where $56 \%$ of 18 breast cancer patients showed a partial response, and $11 \%$ showed stable disease after receiving $100 \mathrm{mg}$ daily (Robertson et al. 1999). A complication in the use of these agents to treat breast cancer is that they also possess antiglucocorticoid activity (Van Look \& Hertzen 1995) and are associated with liver function abnormalities (Robertson et al. 1999). Newer agents are being developed that have reduced antiglucocorticoid activity (Wagner et al. 1999) and it remains to be seen whether more selective antiprogestins will be beneficial in the treatment of breast cancer.

\section{Aromatase inhibitors}

In post-menopausal women, a major amount of oestrogen is generated by the peripheral conversion of androstenedione to oestrone by the p450 enzyme aromatase. The enzyme is found in a variety of tissues, such as fat, stromal tissue and in breast tumours themselves (Santen $e t$ al. 1997), and contributes significantly to levels of circulating oestrogens in these patients. A second source of oestrogens in post-menopausal women is the local production of oestrone from oestrone sulphate, which is present at higher levels within the tumour compared with normal tissue or plasma (Pasqualini et al. 1997). The enzyme responsible for this conversion, oestrone sulphatase, is present in a greater proportion of breast tumours than aromatase and it is suggested that it is responsible for a greater production of oestrogens (Santen et al. 1986). In both cases, oestrone is converted to $17 \beta$-oestradiol within the tumour by $17 \beta$-hydroxysteroid dehydrogenase (17 $\beta$ HSD). It has therefore been proposed that inhibitors that block aromatase, oestrone sulphatase or $17 \beta$-HSD would be effective in controlling the local production of oestrogens in postmenopausal patients.

Traditional second line therapies for the treatment of hormone-dependent tumours that have become refractory to tamoxifen have included high dose progestins, such as megestrol acetate, and non-selective aromatase inhibitors such as aminoglutethimide. Potent and selective new generation aromatase inhibitors such as anastrozole (Arimidex), letrozole, exemestane and vorozole that prevent the peripheral synthesis of oestrogens (Fig. 1) have recently been developed and have been shown to provide clinical benefit as second line therapy in postmenopausal patients (Dowsett 1997).

In clinical trials with post-menopausal patients who have relapsed on tamoxifen therapy, second generation aromatase inhibitors have demonstrated similar response rates to megestrol acetate but with improved duration and patient survival and decreased side effects, in particular less weight gain (Buzdar et al. 1998, Dombernowsky et al. 1998). Anastrozole, however, has shown a significant survival benefit compared with megestrol acetate (Buzdar et al. 1998). Other trials have shown letrozole to be superior to aminoglutethimide (Gershanovich et al. 1998). These agents are, therefore, of proven value as second-line therapy in treating post-menopausal patients with hormone-dependent cancer who have relapsed after treatment with tamoxifen. An assessment of the relative merits of anastrozole and letrozole will require a direct head-to-head comparison of the two drugs. Continuing clinical trials also aim to assess the value of different aromatase inhibitors versus antioestrogens as first-line therapy for post-menopausal patients (Blamey 1997, Harvey 1998) and as adjuvant therapy in the treatment of early disease (Lønning 1998).

A variety of inhibitors of both oestrone sulphatase $(\mathrm{Li}$ et al. 1998) and 17 $\beta$-HSD (Tremblay \& Poirier 1998) have been identified and indeed many progestins inhibit both enzymes (Pasqualini et al. 1998). However, whether such agents will find a place in the clinic is perhaps questionable, given that the plasma level of oestrone and oestrone sulphate is effectively controlled in patients treated with aromatase inhibitors (Lønning et al. 1997, Geisler et al. 1998).

\section{Gonadotrophin-releasing hormone agonists}

Luteinising hormone-releasing hormone (LHRH) agonist analogues were developed to block follicular activity by desensitising the pituitary gland to LHRH. The resulting reduction in $\mathrm{LH}$ in pre- and peri-menopausal women leads to a reduction in the production of oestrogens from the ovaries, and in men to a decrease in the production of testosterone by the testis (Fig. 1; Furr 1989). Drugs such as goserelin (Zoladex), buserelin and leuprolide are 
modified peptides, which can be administered as slowrelease, long-term, 1 or 3 monthly depots, with the advantage over surgical castration in that treatment can be reversed. Clinical trials with these agents have demonstrated them to be effective in 30-60\% of pre-menopausal patients with advanced breast cancer (Blamey et al. 1992, Dowsett et al. 1992). Furthermore, consistent with the mechanism of action, responses are much better in prerather than post-menopausal patients (Dowsett et al. 1992). Treatment with LHRH agonists lowers plasma oestradiol to post-menopausal levels and treatment with goserelin monthly depot has been shown to be as effective as oophorectomy in improving both disease-free and overall survival in pre-menopausal women with advanced breast cancer (Taylor et al. 1998). Recently, a metaanalysis of four randomised trials, including 506 patients, tested the hypothesis that 'complete oestrogen blockade' by combined LHRH agonist plus tamoxifen treatment is more effective than medical ovarian suppression alone (Klijn et al. 1998). The combination treatment was superior to LHRH agonist alone with respect to objective response and both progression-free and overall survival, indicating that the combined treatment modality should be proposed as the new standard treatment in pre-menopausal women with advanced breast cancer. Currently, trials are also being performed to evaluate the effect of increasing oestrogen blockade further by the addition of an aromatase inhibitor, an LHRH agonist and tamoxifen in premenopausal women (Blamey 1997). Finally, the LHRH analogue, goserelin, is currently being investigated in an extensive adjuvant clinical trial programme, particularly in comparison with cytotoxic therapy (CMF: cyclophosphamide, methotrexate and 5-fluorouracil) (Kaufmann 1998) since the effect of CMF in pre-menopausal patients may be mediated by ovarian suppression (Boccardo et al. 1996, Jonat 1998).

LHRH antagonists have been developed more slowly because early compounds lacked sufficient potency and induced histamine release and local inflammation that could be severe (Schmidt et al. 1984, Weinbauer \& Nieschlag 1992, Reissmann et al. 1995, Schally \& Comaru-Schally 1997). More recently, potent LHRH antagonists such as aborelix, have been developed which have little local irritancy potential and can be delivered in depot preparations, although durations of more than one month may be difficult to achieve (Menon et al. 1998). Such compounds have the advantage that they will produce an immediate fall in serum LH and sex steroid hormones in men and women and so will avoid any potential for an initial stimulatory hormone response that can occur, particularly in men, with LHRH agonists. However, since they are competitive antagonists, adequate blood levels must be present continuously to prevent access of LHRH to the receptor. This places severe demands on delivery systems. In contrast, LHRH agonists induce LHRH receptor down-regulation, which recovers more slowly on withdrawal, and so specifications for delivery are likely to be less demanding: this might lead to fewer treatment failures or breakthroughs with LHRH agonists. The results of current phase III trials and direct comparisons with LHRH agonist depots will determine the future place of LHRH antagonists in the therapy of breast and prostate cancer.

\section{Androgen blockade to treat prostate cancer}

The demonstration in the early 1940s that prostatic cancer is dependent upon androgens (Huggins \& Hodges 1941) has led to the development of increasingly sophisticated regimes to treat patients with advanced prostate cancer. Surgical castration is one means to control prostate cancer by reducing the level of circulating androgens. LHRH agonists suppress LHRH receptor content of the pituitary gland and consequently LH secretion and can, therefore, be used in men to achieve chemical castration to treat advanced metastatic prostate cancer (Furr 1989). Goserelin monotherapy is as effective as surgical castration in the treatment of prostate cancer (Kaisary et al. 1991, Vogelzang et al. 1995) with response rates of around 85\% but with the advantage of any adverse effects being reversible.

By analogy with the treatment of breast cancer, nonsteroidal pure antiandrogens such as flutamide, nilutamide and bicalutamide (Casodex) have been developed that antagonise the action of androgens at the level of the androgen receptor (AR) (Fig. 1; Furr 1996). One use of antiandrogens has been to suppress the effect of any initial stimulatory response in patients treated with LHRH analogues, since these agents produce a transient stimulation in LH levels with consequent increase in the production of testosterone (Waxman et al. 1985). The use of bicalutamide (150 mg daily) alone has been demonstrated to provide a similar survival outcome to surgical castration in non-metastatic advanced prostate cancer patients but with the significant advantage of improved sexual interest and physical capacity (Iversen et al. 1998). Continuing clinical trials with bicalutamide as monotherapy will determine the full advantages of the drug both in locally advanced and metastatic disease as well as in early prostate cancer.

A major use of antiandrogens has been in combination with LHRH analogues to achieve complete androgen blockade. This is because androgens, such as androstenedione and dehydroepiandrosterone, are produced by the adrenals and possess about a fifth of the biological activity of testosterone. Moreover, to a small extent these androgens are converted to testosterone in peripheral tissue. LHRH analogues are unable to reduce the levels of these androgens and, therefore, the combination of an 
antiandrogen with an LHRH analogue may provide a more effective therapy (Labrie et al. 1993, Schellhammer et al. 1997a, Sarosdy et al. 1998).

More recently a major comparative study of surgical castration versus surgical castration combined with flutamide has failed to show any advantage for the combination (Eisenberger et al. 1998), which has caused considerable controversy. Interestingly, the actual time to treatment failure and survival are similar for the combination therapy of LHRH with flutamide or surgical castration with flutamide. However, there is a major difference in time to treatment failure and survival between LHRH agonist treatment and surgical castration in these studies, which was not found in a direct comparison of medical and surgical castration alone (Kaisary et al. 1991, Vogelzang et al. 1995). Such a difference in response to equivalent standard therapy might indicate different patient selection and this could explain the observed differences between this and other maximal androgen blockade trials. A meta-analysis (Prostate Cancer Trialists' Collaborative Group 1995) of combination of LHRH agonist and antiandrogen showed a non-significant trend in favour of combination therapy. However, this analysis has been criticised (Klotz \& Newman 1996). There is a lack of consensus about the merits of this analysis since it includes many small studies and a range of antiandrogens, including cyproterone acetate which may have stimulatory activity in some tumours. Moreover, other meta-analyses have shown a significant benefit for maximal androgen blockade (in respect of objective response, risk of progression and overall survival) (Bertagna et al. 1994, Caubet et al. 1997).

Intermittent androgen withdrawal therapy has also been proposed in the treatment of prostate cancer with the objective of preventing the development of tumour resistance to endocrine therapy (Bruchovsky et al. 1997). Cycles of therapy are given to achieve maximal response with therapy reinitiated when tumour escape occurs. Such therapy has the advantage of periods of drug withdrawal and restoration of normal sexual function. This creative concept has been used to good effect in open trials (Bruchovsky et al. 1997), but requires large randomised trials against continuous comparable therapy to determine whether survival advantages can be demonstrated.

There has been considerable controversy over the relative potency of some of the pure antiandrogens, with Luo et al. (1996) championing the superiority of flutamide. Furr (1997), in reviewing the data, has concluded that the majority of preclinical and clinical studies confirm the increased potency and tolerability of bicalutamide.

Clinical studies have demonstrated that bicalutamide is at least as effective as flutamide when used in combination with an LHRH agonist (Schellhammer et al. 1997a) and that the combination of leuprolide with flutamide is significantly less effective than the combination of goserelin or leuprolide with bicalutamide (Sarosdy et al. 1998). When compared with flutamide, bicalutamide also has a superior tolerance profile (Schellhammer et al. 1997a).

The major side-effects of LHRH agonists are loss of sexual activity and hot flushes and for antiandrogens, gynaecomastia is the most frequent side-effect. It will be interesting to see whether sildenafil has any role to play in restoring libido in surgically or medically castrated patients and whether the use of aromatase inhibitors will prevent gynaecomastia. It is also very important to know if the addition of aromatase inhibitors to pure antiandrogens will cause a further significant increase in circulating androgens, that could compromise anti-tumour efficacy, before any recommendations can be made about its value in the prostate cancer setting. Such trials are in progress.

Inhibitors of the enzyme $5 \alpha$-reductase, such as finasteride, have also been developed that prevent the conversion of testosterone into the 5-10 times more potent androgen $5 \alpha$-dihydrotestosterone (DHT). Finasteride is used to treat benign prostate hyperplasia (Gormley et al. 1992). However, inhibiting $5 \alpha$-reductase does not reduce the concentrations of testosterone and, due to the lack of feedback inhibition, could lead to an increase in testosterone concentrations (Lamb et al. 1992, Presti et al. 1992). Recent studies have, therefore, suggested that finasteride monotherapy is inadequate for the treatment of advanced prostate cancer (Ornstein et al. 1996). It is possible that the use of a $5 \alpha$-reductase inhibitor would decrease the production of DHT from adrenal androgens in patients treated with an LHRH agonist. Trials to combine a $5 \alpha$-reductase inhibitor with an antiandrogen in order to maintain sexual function have had some success (Fleshner \& Trachtenberg 1993). Nevertheless, increases in serum testosterone were observed and those with the highest increase developed gynaecomastia. It remains to be established whether the addition of a $5 \alpha$-reductase inhibitor to the combination of LHRH agonist and antiandrogen therapy will provide any additional benefit.

Antiandrogen withdrawal can lead to further tumour responses. It is likely that some of these responses are due to mutation in the androgen receptor because both steroidal and non-steroidal antiandrogens have been shown to act in a stimulatory manner as agonists at a number of mutant receptors (Veldscholte et al. 1992, Sharief et al. 1995, Bubley \& Balk 1996). Antiandrogen withdrawal responses have also been seen with bicalutamide, although less frequently than with flutamide (Dupont et al. 1993, Scher \& Kelly 1993, Sartor et al. 1994, Small \& Carroll 1994, Figg et al. 1995, Liebertz et al. 1995, Nieh 1995, Small \& Srinivas 1995, 
Schellhammer et al. 1997b). However, bicalutamide, unlike flutamide, still inhibits the growth of cell lines expressing mutant receptors and so mutation of these receptors is unlikely to be the complete explanation for androgen withdrawal responses (Veldescholte et al. 1992, Culig et al. 1994, Peterziel et al. 1995, Bubley \& Balk 1996).

\section{Prospects for treating hormone non- responsive endocrine tumours}

Some ER-positive tumours fail to respond to endocrine therapy or eventually develop resistance. Furthermore, approximately a third of breast cancer patients are ER negative and are, therefore, far less likely to respond to endocrine therapy. The treatment of hormone-independent tumours has not, thus far, been as successful as the treatment of those that remain responsive to hormones. The current options available include radiation and combination chemotherapy with, for example, anthracyclines, anti-tumour antibiotics, vinca alkaloids and more recently platins and taxanes. Our increasing knowledge of the genetic changes that occur as tumours develop and progress has uncovered a web of oncogenes and tumour suppressor genes that together conspire to transform a normal hormone-regulated epithelial cell into one that can grow and spread independently from the host regulatory signals. Some of the changes identified to date may offer alternative approaches to control the growth of hormoneindependent tumours but with the advantage of a toxicity profile closer to that of the endocrine therapies than the current poorly selective chemotherapy approaches.

\section{Retinoids}

Retinoids have been known for some time to play a crucial role in regulating the differentiation and proliferation of epithelial cells, and are also potent inducers of apoptosis. Furthermore, there are many cellular and animal studies to indicate that retinoids are effective in preventing or suppressing tumour growth (Gottardis et al. 1996a). The effects of retinoids appear to be mediated by nuclear retinoid receptors that regulate specific gene expression due to their interaction with specific DNA response elements. Broadly two types of retinoid receptor have been identified; retinoic acid receptors (RAR) and retinoid $\mathrm{X}$ receptors (RXR). The retinoid, 9-cis retinoic acid, binds to both types of receptor whereas all-trans retinoic acid is selective for RAR. As a further level of complexity, there are three subtypes of RAR and RXR termed alpha, beta and gamma; each exists in a variety of alternatively spliced forms with different patterns of tissue expression. Finally, the functional retinoid receptor consists of a heterodimer between an RAR and an RXR and the active form of other nuclear hormone receptors consists of a heterodimer with RXR (Mangelsdorf et al. 1993).

Evidence is beginning to emerge that retinoids may have utility in the treatment of cancer in the clinic. Tretinoin (all-trans retinoic acid) has been approved in the USA for acute promyelocytic leukaemia, a condition that involves the $\mathrm{t}(15 ; 17)$ chromosomal translocation between the PML gene and that for RAR $\alpha$ (Gillis \& Goa 1995). The retinoid $\mathrm{N}$-(4-hydroxyphenyl) retinamide (4 HPR; fenretinide) is currently being evaluated for the prevention of breast and prostate cancer. The results thus far (in prostate cancer) have not, however, been encouraging. In a small study involving 22 patients, 8 patients with negative biopsies at the start of the trial were found to be positive by the end of 12 months resulting in the closure of the study (Pienta et al. 1997).

9-Cis-retinoic acid (Panretin; LGD 1057) is a more potent inhibitor of mammary carcinogenesis induced by $\mathrm{N}$-nitroso-N-methylurea (NMU) than all-trans retinoic acid in rats (Anzano et al. 1994). Furthermore, its combination with low levels of tamoxifen was particularly effective, with a doubling in the number of animals that were tumour free at autopsy and significantly diminished tumour numbers and tumour burden. In phase I clinical trials, the dose-related toxicities associated with 9-cis retinoic acid were headache (3/41) and skin toxicity (11/ 41), manifested as mild and limited to skin dryness and erythema, but no tumour responses were observed (Rizvi et al. 1998a). Topical use of the compound has been demonstrated to be effective in approximately a third of patients with Kaposi's sarcoma. Phase II trials should be in progress to evaluate 9-cis retinoic acid in breast and prostate cancer and the National Cancer Institute (NCI) are sponsoring trials to examine the combination of tamoxifen with 9-cis retinoic acid.

More selective retinoid receptor ligands have been developed. For example, LGD 1550 is a potent (1-4 nM) alpha, beta and gamma RAR-selective agonist (Shalinsky et al. 1997). In tumour xenograft models, the compound was very effective in inhibiting growth of a squamous cell carcinoma, but no objective tumour responses were observed in a phase I/II dose-ranging trial in 25 advanced cancer patients (Rizvi et al. 1998b). LGD 1069 (Targretin) is a highly selective RXR agonist with low affinity for RARs. Like 9-cis retinoic acid, LGD 1069 prevents the formation of tumours in the NMU-initiated rat model (Gottardis et al. 1996b) and the combination of LDG 1069 and tamoxifen was more effective than either agent alone (Bischoff et al. 1998). In phase I studies with LGD 1069, liver enzyme changes were the most common doselimiting adverse effects (Miller et al. 1997). Less prominent reactions included hypertriglyceridaemia and hypercalcaemia and it would be interesting to learn whether these effects are mediated by the interaction of 


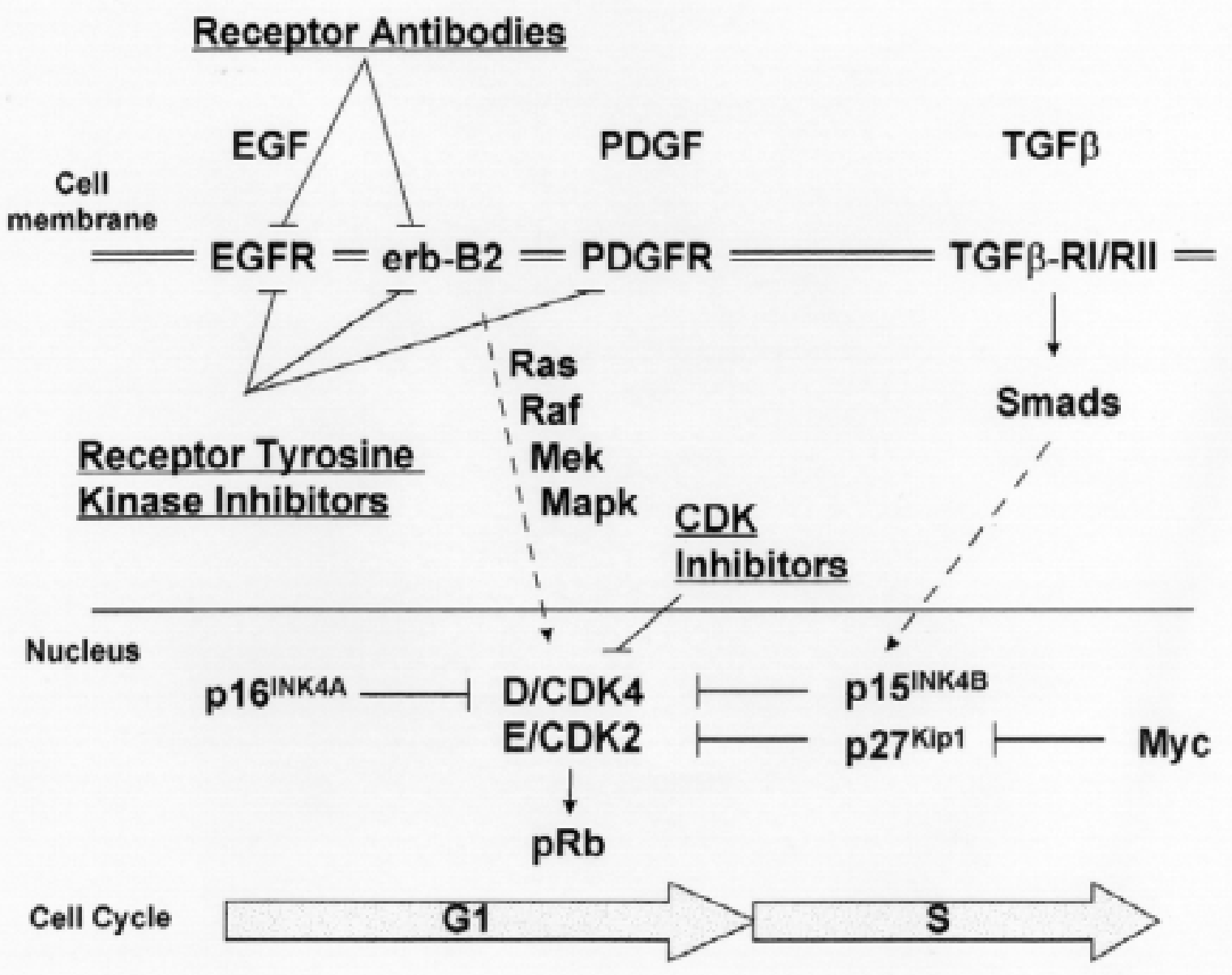

Figure 2 Defective signalling pathways in breast and prostate cancer. Cellular proliferation in tumours is induced by deregulated signalling pathways that increase the activity of cyclin-dependent kinases. Some of the pathways increase the level of cyclin D, an activator of CDK4 and CDK6, whereas others modulate the activity of CDK2 by decreasing the level of CDK inhibitors such as $\mathrm{p} 15^{\mathrm{INK} 4 \mathrm{~B}}$ and $\mathrm{p} 27^{\mathrm{Kip} 1}$. The net effect is accelerated entry into the cell cycle and a lower dependency on exogenous growth factors. A variety of receptor antagonists and kinase inhibitors that block these aberrant signalling pathways are being evaluated in the clinic.

RI/RII, receptor I and II; PDGFR, platelet derived growth factor receptor.

RXR with other nuclear hormone receptors. Notably, the characteristic retinoid toxicities, such as cheilitis, headache, and myalgias/arthralgias, were mild or absent and responses were observed in patients with cutaneous T-cell lymphoma. Clearly, further clinical studies are required to evaluate these interesting new compounds. Time will tell whether retinoids will be effective agents against advanced solid tumours and whether they will be sufficiently well tolerated to consider their use for tumour prevention, as is suggested by a large number of pre-clinical studies.

\section{Aberrant growth factor signalling}

A variety of aberrant signal transduction pathways have been implicated in the growth of human tumours and a variety of drugs are being developed to block these pathways (Fig. 2). The epidermal growth factor (EGF) receptor family comprises a small number (erb-B1 to erbB4) of trans-membrane receptor tyrosine kinases that appear to play an important role in growth of endocrineresponsive tumours. EGF and transforming growth factor $\alpha$ (TGF) are mitogens for a variety of epithelial cells that bind and activate the EGF receptor (EGFR or erb-B1). In some cases, the tumour itself is capable of expressing EGFR ligands thereby providing an autocrine growth 
signal (Sherwood \& Lee 1995). The EGF receptor is overexpressed in a wide range of human epithelial tumours including those of the breast (Harris et al. 1992) and prostate (Sherwood \& Lee 1995). With respect to breast cancer, it is noteworthy that the expression of EGFR is inversely correlated with ER expression (Harris et al. 1992) and associated with a poorer prognosis. Additional members of the EGFR family have also been implicated in tumorigenesis; the erb-B2 gene (the neu oncogene) is amplified in a small proportion of breast and ovarian cancers and is similarly associated with a poor prognosis (Slamon et al. 1989) and erb-B3, a receptor for heregulin, is overexpressed in a variety of solid tumours (Gullick 1996). Ligand binding promotes receptor homo-dimerisation and activation of the intracellular tyrosine kinase (Honegger et al. 1989). In addition, hetero-dimerisation can occur so that, for example, ligand bound EGFR can activate the intracellular domain of erb-B2 (Gulliford et al. 1997). Once activated, the tyrosine kinase domain of a receptor phosphorylates specific sites on the intracellular domain of the partner receptor creating phospho-tyrosine motifs that are specifically recognised by Src homology domain 2 (SH2) domains within additional signal transduction proteins (Moran et al. 1990). As a result of the interaction, these proteins are recruited to the cell membrane initiating a cascade of signals that ultimately can lead to cell division.

Developing agents that antagonise EGFR action may, therefore, be particularly effective against hormoneindependent breast and prostate cancer and several such compounds are now being evaluated in clinical trials. One approach has been to use monoclonal antibodies that bind to the extracellular domain of the EGFR (Modjtahedi et al. 1996) or erb-B2 (Baselga et al. 1998). An antibody to EGFR (C225) is in phase I/II trials in breast cancer in combination with paclitaxel and with doxorubicin for advanced prostate cancer. The efficacy of a recombinant humanised monoclonal antibody against erb-B2 (trastuzumab; Herceptin) has been assessed in clinical trials with breast cancer patients with metastatic disease and has recently been approved by the Food and Drug Administration (FDA). Objective responses were seen in 5 of 43 assessable patients, and included one complete remission and four partial remissions (Baselga et al. 1996). Pre-clinical models demonstrate that a combination of paclitaxel and the erb-B2 antibody resulted in superior tumour growth inhibition when compared with either paclitaxel or antibody alone (Baselga et al. 1998). Clinical trials combining Herceptin with cisplatin, paclitaxel or anthracycline plus cyclophos-phamide indicate that the addition of antibody doubles the response to chemotherapy in a group of erb-B2-positive patients (Slamon $e t$ al. 1998).
An alternative approach has been to identify low molecular weight inhibitors that bind to the ATP binding site of the EGFR tyrosine kinase (Klohs et al. 1997). These agents are potent and selective inhibitors of the kinase in vitro and are able to block receptor autophosphorylation in cells stimulated with EGF (Moyer et al. 1997, Lydon et al. 1998). Pre-clinical models have demonstrated EGFR tyrosine kinase (TK) inhibitors to be well tolerated and effective agents against a variety of EGF-dependent tumour xenografts grown in athymic nude mice including those of vulval, prostate and ovarian origin (Woodburn et al. 1997). Interestingly, EGFR TK inhibitors not only produce the anticipated cytostatic response in tumour models but are also capable of producing tumour regression (Woodburn et al. 1997, Lydon et al. 1998) suggesting that these agents alter the balance between mitogenesis and apoptosis (Moyer et al. 1997). Furthermore, studies in cell culture suggest that the combination of an EGFR antibody with chemotherapy (Hoffmann et al. 1997) or radiation (Balaban et al. 1996) may act synergistically to induce tumour regression, suggesting that EGFR TK inhibitors could enhance the effect of conventional agents. Since EGFR and erb-B2 heterodimerise in cells and act synergistically in transgenic models to enhance tumour formation (Muller et al. 1996), then EGFR TK inhibitors may also be effective against tumours that overexpress erb-B2. A number of EGFR TK inhibitors (ZD 1839, CP 358774, CGP 59326) are in phase I/II clinical trials.

Breast and prostate tumours also express plateletderived growth factor (PDGF). The prognostic significance of the expression of PDGF is suggested by studies demonstrating that breast cancer patients with tumours staining positively for PDGF have a highly significant shorter survival than patients with no immunostaining (Seymour \& Bezwoda 1994). Furthermore, patients with PDGF-positive tumours treated with combination chemotherapy have a significantly lower response rate than those that have PDGF-negative tumours. Other studies have suggested that PDGF may be an important mediator of benign prostate hyperplasia in response to inflammation (Vlahos et al. 1993). The immunosuppressive drug and dihydroorotate dehydrogenase inhibitor, leflunomide (SU101) may also interfere with PDGF signalling pathways since it has, in addition, been demonstrated to be a tyrosine kinase inhibitor (Xu et al. 1996), including that of the PDGF receptor. The compound is currently in phase II studies in patients with hormone-refractory prostate cancer.

\section{Cell cycle inhibition}

The observation that a marker of cell proliferation such as Ki-67 is associated with reduced patient survival and disease-free interval in breast (Archer et al. 1995) and 
prostate (Stapleton et al. 1998) cancer suggests that enhanced cellular proliferation contributes to tumour progression. Moreover, there is evidence for an increase in cellular proliferation for recurrent prostate tumours after radiotherapy or surgery (Grossfeld et al. 1998). There are many pathways which could be deregulated in tumours in order to increase cell proliferation, including the overexpression of growth factors and their receptors (e.g. TGF- $\alpha / E G F R$ ), the loss of growth inhibitory pathways (e.g. TGF- $\beta$ ), the loss of tumour suppressor genes (e.g. the retinoblastoma protein $\mathrm{pRb}$ ) and the stimulation of endocrine-responsive tumours by steroid hormones.

Although we still do not understand at the molecular level precisely how steroids regulate entry into the cell cycle, much has been learnt recently about some of the principal factors involved. In general, steroid hormones regulate the activity of CDKs through the accumulation of $\mathrm{D}$ cyclins with little change in the level of cyclin E, CDK2 or the CDK inhibitor proteins such as p $21^{\mathrm{Cip} 1}$ and $\mathrm{p} 27^{\mathrm{Kip} 1}$ (Planas-Silva \& Weinberg 1997). The increase in cyclin D1 activates CDK4 and CDK6 which phosphorylate $\mathrm{pRb}$. This promotes the release of $\mathrm{pRb}$ from the E2F family of transcription factors allowing them to activate the transcription of genes involved in S phase transition (Sherr 1996). Model cell systems have provided evidence that treating breast cancer cells with oestrogens (Watts et al. 1995) or progestins (Musgrove et al. 1993) stimulates the accumulation of cyclin D1 and that the artificial elevation of cyclin D1 can mimic the mitogenic effect of steroids (Musgrove et al. 1996). Furthermore, the treatment of ERpositive cells with antioestrogens reduces the level of cyclin D1 and the cells accumulate in the G1 phase of the cell cycle (Watts et al. 1995). These studies have been supported by experiments in mice that demonstrate that oestrogens stimulate the expression of cyclin D1 in mammary epithelial cells and that progestins further enhance the level of cyclin D1 mRNA (Said et al. 1997). It appears unlikely that the ER directly regulates transcription of the cyclin D1 gene (Altucci et al. 1996), suggesting that it is probably acting further upstream in the signalling pathway. In addition to changes in cyclin D1CDK4 activity, oestrogens stimulate cyclin E-CDK2 activity by promoting the displacement of the CDK inhibitor p21 Cip1 (Planas-Silva \& Weinberg 1997).

Approximately half of primary breast cancers overexpress cyclin D1 (Bartova et al. 1994, Marsh \& Varley 1998) and the gene encoding this protein is amplified in about a third of these cases, suggesting that increases in the level of cyclin D1 could promote breast tumour growth. In support of this, transgenic mice overexpressing cyclin D1 driven by the mouse mammary tumour virus promoter, demonstrate abnormal mammary cell proliferation and develop mammary adenocarcinoma after a latency period of greater than a year (Wang et al.
1994). Interestingly, female mice that are null for the cyclin D1 gene show a defect in mammary epithelial proliferation during pregnancy indicating that cyclin D1 is a critical mediator of steroid hormone-induced cell proliferation in the mammary gland (Sicinski et al. 1995). A recent twist in this story has been the demonstration that cyclin D1 can bind to and activate the ER directly (Zwijsen et al. 1997) and it could, therefore, be speculated that the ER may mediate the oncogenic effects of cyclin D1 in breast tumours. Interestingly, tumours that are ER positive also have a tendency to express higher amounts of cyclin D1 (Gillett et al. 1996), but this could either indicate that oestrogens stimulate the level of cyclin D1 or that cyclin D1 promotes the growth of breast tumours by binding and activating ER. No matter how cyclin D1 is working, it is important to note that antioestrogens can inhibit this ligand-independent ER activation in cell lines forced to overexpress cyclin D1 (Pacilio et al. 1998). One of the natural protein inhibitors of CDK4 is $\mathrm{p} 16^{\mathrm{INK} 4 \mathrm{~A}}$. Inactivation of the p16 gene by deletion, mutation, or silencing of gene transcription by methylation, have all been observed in a variety of solid tumours including breast cancer (Geradts \& Wilson 1996, Marsh \& Varley 1998), but only rarely in prostate cancer (Jarrard et al. 1997). Animal models suggest that p16 is a tumour suppressor gene and argue that the loss of p16 may release the inhibition of D1/CDK4 activity thus promoting cell cycle entry. More recently, however, the picture has become more complicated by the finding that a second protein, encoded in an alternative reading frame (ARF) of the INK4A gene locus, is also a tumour suppressor protein that functions by regulating p53 levels (Chin et al. 1998). It would appear that both the p16 and ARF protein are important in preventing unregulated cell proliferation and, therefore, contribute to tumour progression.

Other changes in cell cycle regulatory proteins have been observed in endocrine-responsive tumours besides changes in cyclin D1, p16 and ARF. Of particular interest has been the observation that low levels of $\mathrm{p} 27^{\mathrm{Kip} 1}$, and to a lesser extent elevated levels of cyclin E, are associated with poor prognosis in a variety of solid tumours including breast (Porter et al. 1997) and prostate (Tsihlias et al. 1998). As cyclin $\mathrm{E}$ is an activator of CDK2, and $\mathrm{p} 27^{\mathrm{Kip} 1}$ an inhibitor, these results suggest that an increase in the activity of CDK2 is important in tumour progression, although it is unclear at the present time as to whether these changes are cause or effect. Similarly, amplification and overexpression of the cyclin E gene has been observed in ovarian cancer; however, there is little evidence for amplification of the cyclin $\mathrm{E}$ gene in breast tumours (Courjal et al. 1996). Only a few examples of mutation or deletion of the $\mathrm{p} 27^{\mathrm{Kip} 1}$ gene have been reported, rather it has been proposed that other proteins that regulate the level of $\mathrm{p} 27^{\mathrm{Kip} 1}$ may be aberrant in tumours, resulting in 


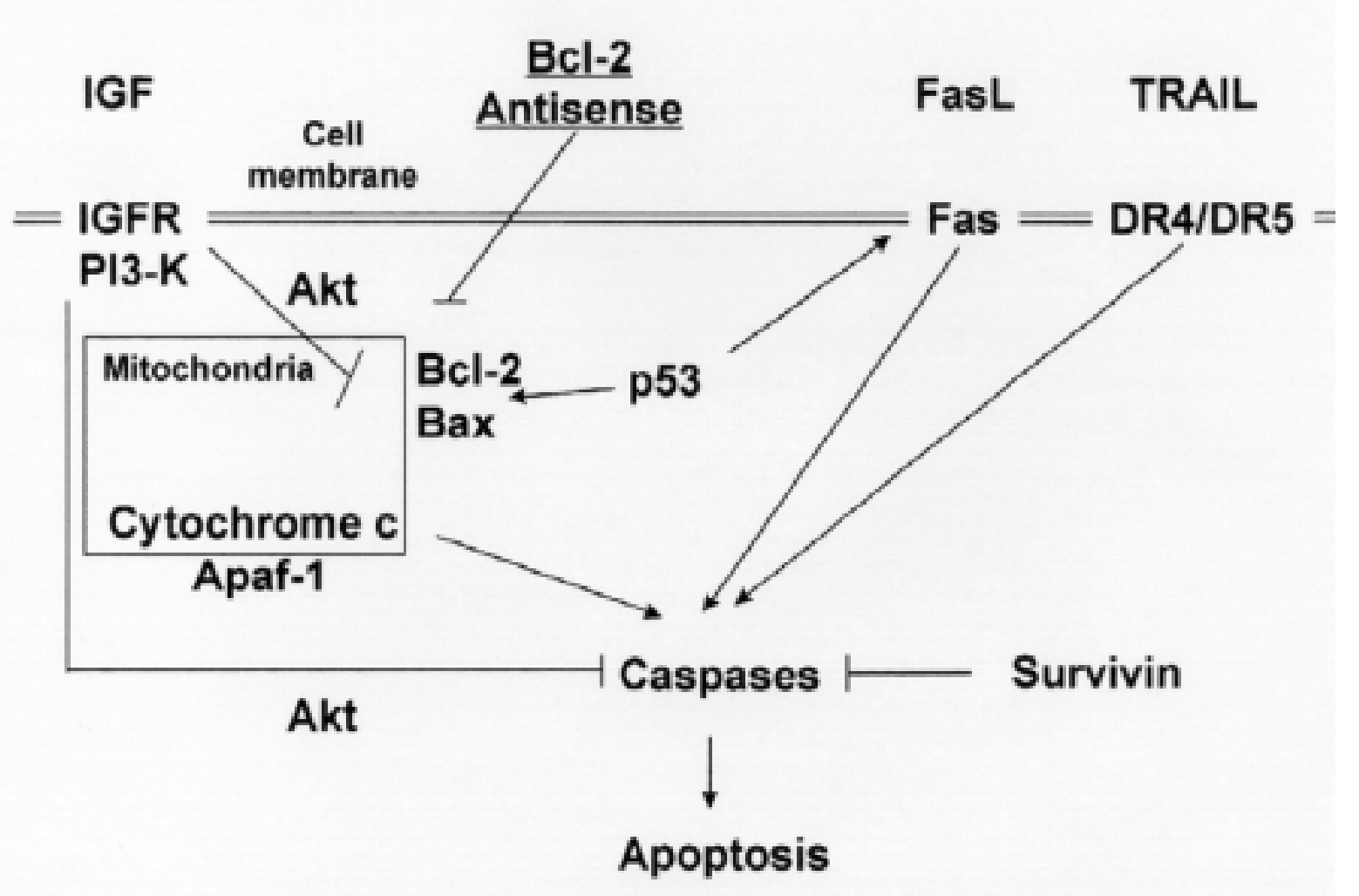

Figure 3 Increased survival signalling in cancer. A number of defective apoptosis pathways have been identified in breast and prostate tumours. The loss of functional p53 leads to reduced apoptosis in response to DNA damage and elevated levels of Bcl-2 and survivin help to protect tumour cells from apoptosis. Insulin-like growth factors act as survival factors and part of their activity appears to be mediated by the activation of PI3 kinase. Bcl-2 antisense may increase the effectiveness of radio- and chemotherapeutic agents by reducing the ability of the tumour to prevent apoptosis.

IGFR, insulin-like growth factor receptor; Apaf-1, apoptotic protease-activating factor 1; DR, death receptor.

the enhanced destruction of the CDK inhibitor (Loda et al. 1997). The levels of $\mathrm{p} 27^{\mathrm{Kip} 1}$ can be regulated by a variety of negative growth factor and oncogene signalling pathways. For example, TGF- $\beta$ induces increases in the level of the CDK inhibitor $\mathrm{p} 15^{\mathrm{INK} 4 \mathrm{~B}}$, resulting in the displacement of $\mathrm{p} 27^{\mathrm{Kip} 1}$ from CDK4 to CDK2 and the inhibition of this kinase (Reynisdottir et al. 1995). Furthermore, mutations within the transcription factor SMAD4/DPC4, a mediator of TGF- $\beta$ signalling, occur at low frequency within a variety of tumours, including those of the breast (Schutte et al. 1996) and prostate (MacGrogan et al. 1997). The levels of $\mathrm{p} 27^{\mathrm{Kip} 1}$ are also influenced by the activation of the c-myc oncoprotein. Increased c-myc induces cyclin E/CDK2 activity. This, in turn, phosphorylates $\mathrm{p} 27^{\mathrm{Kip} 1}$ promoting its dissociation from CDK2 complexes and its subsequent degradation (Muller et al. 1997). The amplification and overexpression of the myc oncogene is observed in approximately a quarter of primary breast cancers and is associated with a poor prognosis (Varley et al. 1987, Roux-Dosseto et al. 1992). Therefore, mutations in SMAD4 or the overexpression of c-myc are likely to make tumour cells more sensitive to factors that elevate D cyclins. Indeed, the regulation of D cyclins by ras may help explain the cooperation of ras and myc to transform primary rat embyro fibroblasts (Leone et al. 1997).

The large body of evidence implicating aberrant cell cycle factors with the progression of endocrine-responsive tumours suggests that small molecule inhibitors of CDKs could be effective agents in controlling this disease. For example, a broad spectrum CDK inhibitor, flavopiridol (NSC 649,890), derived from a natural alkaloid obtained from the Indian plant Dysoxylum benectariferum, has been developed (Sedlacek et al. 1996) and is currently in phase II clinical trials. Flavopiridol inhibits CDK1, CDK2, CDK4 and CDK7 with similar potencies (100 to $400 \mathrm{nM})$. It induces cytotoxicity in cells at 20-200 nM with some evidence for apoptosis and is effective in animal tumour 
models and, in particular, against prostate cancer xenografts (Sedlacek et al. 1996). Many pharmaceutical companies are aiming to develop more selective CDK inhibitors that may prove effective in treating tumours that have developed hormone independence.

\section{Apoptosis}

It has become clear over the last few years that tumour cells, in addition to having deregulated mitogen signalling pathways, have aberrant cell death pathways providing them with a greater chance for survival (Fig. 3). Apoptotic mechanisms also play an important role in mediating the response to endocrine therapy since an increase is observed in the number of apoptotic bodies within tumours in patients treated with antioestrogens (Ellis et al. 1997) and antiandrogens (Montironi et al. 1998). A number of oncogenes and tumour suppressor genes such as Bcl-2 and p53 have roles in regulating apoptosis. Bcl-2 appears to protect cells from apoptosis by preventing the release from mitochondria of factors such as cytochrome $\mathrm{c}$ that are required to activate destructive caspase proteases (Reed 1997, Kroemer et al. 1998). Bcl-2 is overexpressed in a proportion of breast and prostate tumours and may, therefore, be expected to provide a survival advantage. However, an examination of breast cancer patients has demonstrated that the expression of $\mathrm{Bcl}-2$ is tightly associated with ER expression and that those patients with elevated levels of Bcl-2 appeared to benefit most from endocrine therapy (Gee et al. 1994, Berardo et al. 1998). Studies in cell culture may provide an explanation for this link since oestrogens stimulate the expression of Bcl-2, possibly as a means to reduce cell death whilst stimulating mitogenesis (Teixeira et al. 1995). Moreover, the same authors demonstrate that, in the presence of oestrogen, the MCF-7 breast cancer cell line is more resistant to apoptosis induced by adriamycin than when the ER is antagonised with a pure antioestrogen (ICI 164,384). That this effect is mediated by Bcl-2 is suggested by the observation that the effect of oestrogen can be mimicked by the exogenous expression of Bcl-2. If such in vitro studies translate to the clinic, then they would suggest that cytotoxic drugs administered in combination with tamoxifen to lower Bcl-2 levels could benefit patients. Some studies in prostate cancer have suggested a correlation between the expression of Bcl-2 and poor prognosis (Bauer et al. 1996, Matsushima et al. 1997), whereas other studies have suggested no correlation (Grossfeld et al. 1998) and show that a high level of Bcl2 is associated with early prostate cancer (Stattin et al. 1996). Interestingly, androgen-independent prostate tumours express higher levels of Bcl-2 (McDonnell et al. 1992) and their treatment with hormone ablation therapy increases the level of Bcl-2 (Stattin et al. 1996). These observations suggest that Bcl-2 could promote a survival advantage against apoptosis induced by hormone withdrawal. If $\mathrm{Bcl}-2$ promotes cell survival in response to radiotherapy and chemotherapy, then it would be expected that the cancers of patients expressing high levels of Bcl2 would have a poorer response to treatment. There is some evidence that this is true in prostate cancer (Huang et al. 1998), where a significantly greater number of tumours from patients who failed radiation therapy expressed Bcl-2. Because the regulation of apoptosis by $\mathrm{Bcl}-2$ is complex, involving the interaction of a number of related proteins which either promote or prevent apoptosis, it is likely that additional proteins are deregulated in endocrine-responsive tumours to reduce the apoptosis threshold. For example, Bax is one family member that antagonises the action of Bcl-2, whose expression is lower in a subset of metastatic breast cancer patients that respond poorly to chemotherapy (Krajewski et al. 1995). Antisense therapies directed towards the Bcl2 oncogene are now being evaluated in the clinic in patients with non-Hodgkin lymphoma, a tumour which often contains a $\mathrm{t}(14 ; 18)$ translocation involving the Bcl2 gene and increased amounts of the protein (Cotter 1997). If successful, it will be interesting to determine whether reducing the level of $\mathrm{Bcl}-2$ in androgen-independent prostate cancer will promote tumour regression, either as stand-alone therapy, or in combination with radiation or chemotherapy.

The level of the tumour suppressor protein p53 is stabilised in response to DNA damage (Lane \& Hall 1997). Since p53 is a transcription factor, its stabilisation enhances the expression of p53-regulated genes. One of the genes regulated by $\mathrm{p} 53$ encodes the CDK inhibitor $\mathrm{p} 21$ to promote cell cycle arrest (Deng et al. 1995). Other genes stimulated by p53 include Bax (Miyashita et al. 1994) and Fas (Owen-Schaub et al. 1995) which promote apoptosis. Furthermore, p53 suppresses the expression of Bcl-2 (Miyashita et al. 1994) thereby further sensitising cells to apoptosis. The p53 gene is frequently mutated in a wide variety of solid tumours, including those of the breast and prostate, and is linked with poor prognosis (Gasparini et al. 1998). The loss of p53 or the expression of a dominant negative mutant can prevent apoptosis in response to radiation in a transgenic mouse model (Lowe et al. 1993) and the loss of functional p53 increases the radioresistance of tumour cell lines (McIlwrath et al. 1994). Using immunohistochemistry, it is not clear whether the level of p53 (an indication of aberrant p53 function) predicts clinical response to therapy in primary breast cancer but interesting associations have been made between the presence of particular p53 mutations and the poor response of the tumour to treatment with tamoxifen, radiotherapy or chemotherapy (Bergh et al. 1995, Aas et al. 1996). Studies in patients suggest that the level of p53 is elevated in prostate tumours recurring after radiotherapy 
(Grossfeld et al. 1998, Huang et al. 1998), perhaps indicating that there is selection of tumour cells with mutant $\mathrm{p} 53$, because of their reduced propensity to undergo apoptosis or cell cycle arrest.

The role of additional factors in regulating apoptosis to promote endocrine-responsive tumour progression or response to therapy remains to be established. For example, insulin-like growth factors (IGF) are mitogens for breast and prostate cells that appear to function as survival factors reducing the level of apoptosis. Recent studies have suggested that high plasma levels of IGF-I are associated with an increased risk of developing prostate cancer (Chan et al. 1998) and IGF family members may be indicators of prognosis in breast cancer but, because of the number of factors involved, the picture remains complicated (Lee et al. 1998). One of the second messenger pathways that appears to be involved in suppressing apoptosis is the phosphoinositide pathway. A number of growth factors including IGFs activate phosphatidylinositol-3 kinase (PI3K) resulting in the elevation of 3-phosphorylated inositol lipids. These bind to a variety of proteins that contain a pleckstrin homology domain, thereby recruiting them to the plasma membrane and inducing enzyme activity (Shepherd et al. 1998). One such protein is the oncoprotein Akt, also known as protein kinase $\mathrm{B}$, and the expression of a constitutively active form of Akt can suppress apoptosis in a variety of models, possibly by indirectly modulating Bcl-2 activity (Datta $e t$ al. 1997). More recently, it has been demonstrated that Akt can phosphorylate and inhibit the activity of caspase 9 (Cardone et al. 1998), providing a further potential mechanism to explain the ability of Akt to suppress apoptosis. Interestingly, the PTEN tumour suppressor gene encodes a protein with phosphoinositol-3 phosphatase activity that counters the activity of PI3K (Maehama \& Dixon 1998). Disruption of the gene is associated with Cowden's disease and prediposes these families to breast cancer (FitzGerald et al. 1998). Futhermore, the gene is mutated, deleted or repressed in approximately $10-20 \%$ of spontaneous cases of prostate cancer (Cairns et al. 1997, Whang et al. 1998). The loss of PTEN may therefore lead to elevated levels of phosphotidylinositol-3 lipids, increased activity of proteins such as Akt and, therefore, reduced apoptosis.

Additional factors that may influence apoptosis in tumours include fas, and other members of the tumour necrosis factor (TNF) receptor family. Recent studies have suggested that cell lines derived from primary prostate tumours are sensitive to fas-mediated apoptosis, whereas those derived from metastases are more resistant (Hedlund et al. 1998). It will be of interest to determine whether these differences are due to changes in the level of proteins such as Bcl-2. In addition, novel apoptosis genes associated with endocrine-responsive tumours continue to be identified. One such gene is survivin, which is related to an insect virus protein IAP (inhibitor of apoptosis). Survivin is undetectable in terminally-differentiated adult tissues but is prominently expressed in lung, colon, pancreas, prostate and breast tumours (Ambrosini et al. 1997). Other studies have identified a novel TNF-related apoptosis-inducing ligand (TRAIL) that induces apoptosis of many transformed cell lines, but not of normal tissues, due to the latter expressing decoy receptors that bind TRAIL but lack the intracellular effector death domain (Pan et al. 1997).

Evidence is beginning to emerge that as endocrineresponsive tumours develop they become more resistant to apoptosis through either the increased expression of proteins that prevent apoptosis or the loss of proteins that promote apoptosis. In addition, the treatment of endocrine-responsive tumours with endocrine agents, radiation or chemotherapy is likely to select for cells with increased resistance to apoptosis. Identifying pharmacological agents that can either suppress these antiapoptotic pathways or override them by activating apoptosis pathways directly should, therefore, provide new approaches to treat tumours directly or sensitise them to conventional agents in order to improve efficacy.

\section{Angiogenesis}

A proliferating tumour mass, whether the primary tumour or a small clump of cells lodged at a distant metastatic site, can only grow beyond a couple of millimetres in size before physical constraints prevent the essential supply of nutrients. It is, therefore, essential for tumours to establish their own vasculature in order to be able to survive and grow (Bicknell \& Harris 1996, Eckhardt \& Pluda 1997). Exploiting this angiogenic process has become an attractive ploy to target a wide variety of solid tumours with the added bonus that resistance to therapy is less likely to develop, because the target is an endothelial cell rather than a genetically unstable tumour cell (Boehm et al. 1997).

There is now good evidence that endocrine-responsive tumours produce a variety of positive and negative angiogenic factors that influence the vascularisation process. Some of the positive factors that encourage the formation of new blood vessels include members of the fibroblast growth factor (FGF), vascular endothelial growth factor (VEGF) families, pleiotrophin, placental growth factor, midkine and thymidine phosphorylase (platelet-derived endothelial cell growth factor) (Relf et al. 1997, Choudhuri et al. 1997, Ferrer et al. 1997), whilst the angiogenic inhibitors include angiostatin (O'Reilly et al. 1994) and endostatin (Boehm et al. 1997). Because of continuous tumour cell proliferation, the centre of the tumour becomes hypoxic. The lack of oxygen rapidly stimulates the tumour cells to express VEGF which then 


\section{Tumour Cell}

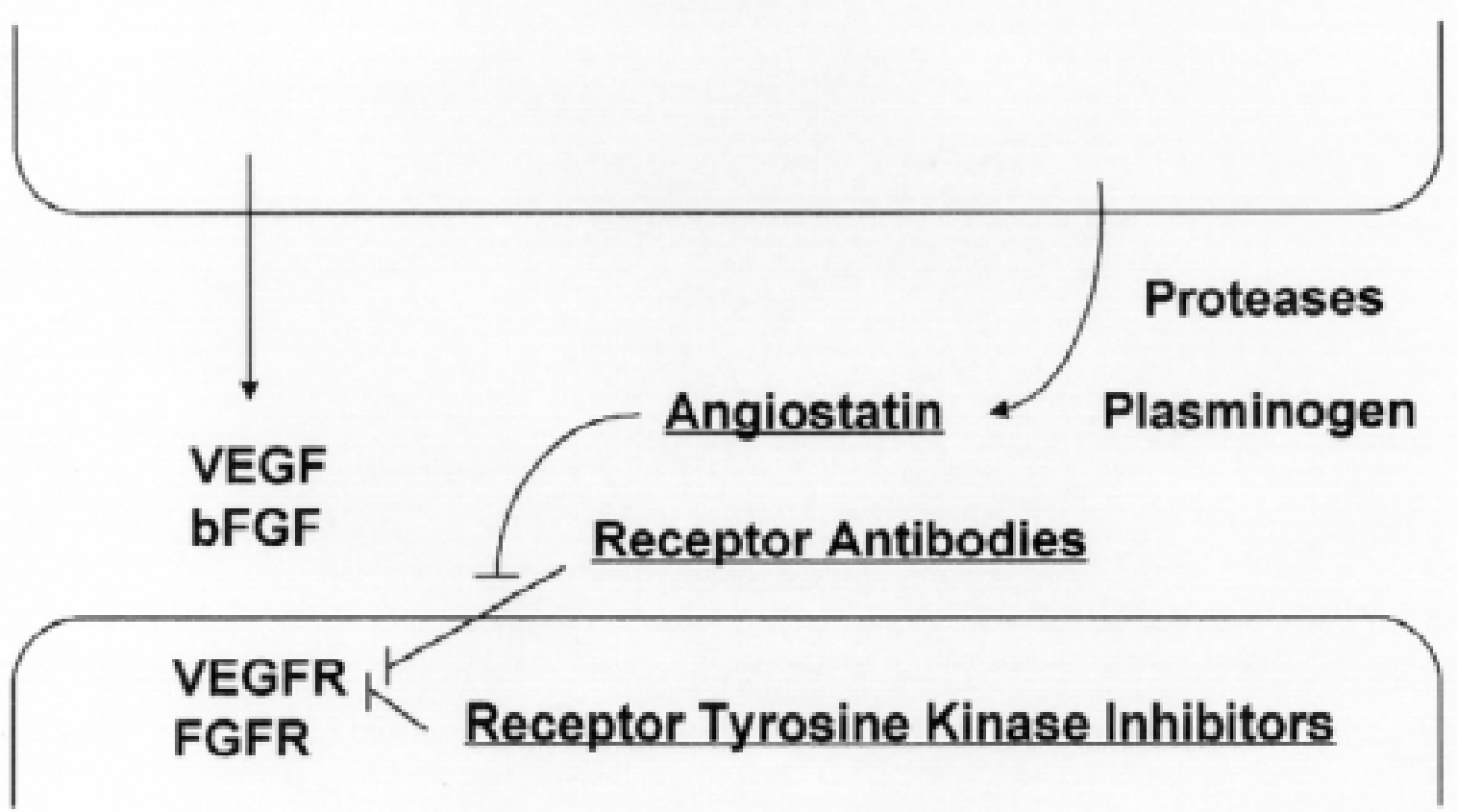

\section{Vascular Endothelial Cell}

Figure 4 Inhibiting angiogenesis. Tumour cells produce a variety of angiogenic and antiangiogenic factors that influence the growth of the primary and secondary metastatic tumours. Biopharmaceuticals are being developed that mimic the activity of angiostatin to suppress angiogenesis. Other approaches to selectively prevent angiogenesis include inhibition of the receptor for VEGF (VEGFR) using receptor antagonists and kinase inhibitors.

induces the growth of new vasculature in order to nourish the tumour (Shweiki et al. 1992). The importance of factors such as VEGF to neo-vascularisation and tumour growth has been demonstrated in animal models. The treatment of nude mice with a neutralising anti-VEGF antibody prevented the growth of the human prostate tumour cell line DU 145 (Borgstrom et al. 1998). Furthermore, a dominant-negative Flk-1 (a receptor for VEGF), contained within a retrovirus to permit its delivery to the endothelial cells of a nude mouse in vivo, is able to suppress the growth of a variety of solid tumour types including those of the breast and ovary (Millauer et al. 1996). As far as angiogenesis inhibitors are concerned, it is interesting that, in an animal model, a primary tumour is able to inhibit the growth of remote metastases and that the removal of the primary tumour provides a stimulus for the metastases to neovascularise and grow (O'Reilly et al. 1994). A fragment of plasminogen, termed angiostatin, is produced by primary tumours and the systemic administration of angiostatin is capable of inhibiting the growth of solid tumours in mice (O'Reilly et al. 1994, 1996). It has also been demonstrated that prostate tumour cell lines express enzymes that can convert plasminogen or plasmin into angiostatin (Gately et al. 1996). Together, these results indicate that tumour growth is achieved through a balance of both positive and negative angiogenic factors.

Measuring the extent of vascularisation in tumours by determining the microvessel count (MVC) has provided a link between the apparent level of angiogenesis and poor prognosis in a variety of endocrine-responsive tumour types (Weidner 1998). An examination of prostate cancer patients demonstrated that the mean MVC was higher in patients with metastases than those without (Weidner et al. 1993). In a study of both node-positive and node-negative breast cancer patients, MVC was determined to be the most accurate prognostic factor for both disease-free and overall survival (Gasparini et al. 1998, Jacquemier et al. 
1998). Although essential in the developing embryo, angiogenesis in the adult is limited to menstruation and wound healing. Therefore, a targeted inhibitor of angiogenesis is anticipated to arrest the growth of the primary tumour, and consequently any metastases, with minimal side effects and with far less chance for resistance to develop. There is considerable excitement, together with a lot of hype, about the development of angiogenesis inhibitors (Augustin 1998, Harris 1998, Marshall 1998, Phillips 1998). It has been suggested that because of the panoply of angiogenic factors that a non-specific inhibitor of angiogenesis, such as a suramin-like compound, will be required (Relf et al. 1997) and thalidomide is being reexamined for use in patients, now that it has been recognised as an inhibitor of angiogenesis (D'Amato et al. 1994). Other approaches target the tumour endothelial cell. For example, CM101 is an analogue of a bacterial polysaccharide that selectively binds to tumour endothelium and stimulates the death of the cells by inducing inflammation (Wamil et al. 1997), and TNP-470 is an analogue of the antibiotic fumagillin that inhibits the growth of endothelial cells (Castronovo \& Belotti 1996). More targeted agents include angiostatin and endostatin as well as antibodies to VEGF and inhibitors (SU5416, ZD4190) of the VEGF receptor tyrosine kinase (Strawn et al. 1996, Ogilvie et al. 1999) (Fig. 4). Many of these agents are now in clinical trials. Despite the many claims surrounding angiostatin and endostatin they still need to clear a number of hurdles before they will be available to test in the clinic. Drugs that target the endothelial cell should be effective against a wide variety of solid tumours and, as an added bonus when treating patients with endocrine cancer, should be equally effective against both hormone-dependent, as well as hormone non-responsive tumours. Despite the excellent activity of antiangiogenic drugs in animal models, the importance of angiogenesis and vasculature remodelling for tumour growth in humans, compared with animal models, remains to be established. The results of clinical trials with these novel agents are, therefore, awaited eagerly.

\section{Hope for the future}

Our understanding of the mechanisms that regulate endocrine-responsive tumour development have changed radically since the association between steroid sex hormones and tumour growth was first recognised at the turn of the century. We are now poised to exploit this increased level of understanding with the development of valuable new drugs with which to treat these tumours. The pioneering basic research work during the 1980s has been translated into new cancer therapeutics that are progressing through clinical trials in the 1990s. It is hoped that some will provide significant benefit to patients at the start of the new millennium.

\section{Acknowledgements}

We are grateful to our many colleagues at Zeneca Pharmaceuticals, and in particular to Alison Sheppard, for their comments and suggestions.

\section{References}

Aas T, Borresen AL, Geisler S, Smith-Sorensen B, Johnsen H, Varhaug JE, Akslen LA \& Lonning PE 1996 Specific P53 mutations are associated with de novo resistance to doxorubicin in breast cancer patients. Nature Medicine 2 811-814.

Altucci L, Addeo R, Cicatiello L, Dauvois S, Parker MG, Truss M, Beato M, Sica V, Besciani F \& Weisz A 1996 17ß-Estradiol induces cyclin D1 transcription, p36D1-p34cdk4 complex activation and $\mathrm{p} 105 \mathrm{Rb}$ phosphorylation during mitogenic stimulation of G1 arrested human breast cancer cells. Oncogene 12 2315-2324.

Ambrosini G, Adida C \& Altieri DC 1997 A novel anti-apoptosis gene, survivin, expressed in cancer and lymphoma. Nature Medicine 3 917-921.

Anzano MA, Byers SW, Smith JM, Peer CW, Mullen LT, Brown CC, Roberts AB \& Sporn MB 1994 Prevention of breast cancer in the rat with 9-cis-retinoic acid as a single agent and in combination with tamoxifen. Cancer Research 54 46144617.

Archer SG, Eliopoulos A, Spandidos D, Barnes D, Ellis IO, Blamey RW, Nicholson RI \& Roberston JF 1995 Expression of ras p21, p53 and c-erbB-2 in advanced breast cancer and response to first line hormonal therapy. British Journal of Cancer 72 1259-1266.

Augustin HG 1998 Antiangiogenic tumour therapy: will it work? Trends in Pharmacological Science 19 216-222.

Balaban N, Moni J, Shannon M, Dang L, Murphy E \& Goldkorn T 1996 The effect of ionizing radiation on signal transduction: antibodies to EGF receptor sensitize A431 cells to radiation. Biochimica et Biophysica Acta 1314 147-156.

Bardon S, Vignon F, Chalbos D \& Rochefort H 1985 RU486, a progestin and glucocorticoid antagonist, inhibits the growth of breast cancer cells via the progesterone receptor. Journal of Clinical Endocrinology and Metabolism 60 692-697.

Barkhem T, Carlsson B, Nilsson Y, Enmark E, Gustafsson J \& Nilsson S 1998 Differential response of estrogen receptor alpha and estrogen receptor beta to partial estrogen agonists/ antagonists. Molecular Pharmacology 54 105-112.

Bartova J, Lukas J, Müller H, Lützhøft D, Strauss M \& Bartek J 1994 Cyclin D1 protein expression and function in human breast cancer. International Journal of Cancer 57 353-361.

Baselga J, Tripathy D, Mendelsohn J, Baughman S, Benz CC, Dantis L, Sklarin NT, Seidman AD, Hudis CA, Moore J, Rosen PP, Twaddell T, Henderson IC \& Norton L 1996 Phase II study of weekly intravenous recombinant humanized antip185HER2 monoclonal antibody in patients with HER2/neuoverexpressing metastatic breast cancer. Journal of Clinical Oncology 199614 737-744. 
Baselga J, Norton L, Albanell J, Kim YM \& Mendelsohn J 1998 Recombinant humanized anti-HER2 antibody (Herceptin) enhances the antitumor activity of paclitaxel and doxorubicin against HER2/neu overexpressing human breast cancer xenografts. Cancer Research 58 2825-2831.

Bauer JJ, Sesterhenn IA, Mostofi FK, McLeod DG, Srivastava S \& Moul JW 1996 Elevated levels of apoptosis regulator proteins 553 and bcl-2 are independent prognostic biomarkers in surgically treated clinically localized prostate cancer. Journal of Urology 156 1511-1516.

Baum M 1997 Tamoxifen. Endocrine-Related Cancer 4 237-243.

Berardo MD, Elledge RM, de Moor C, Clark GM, Osborne CK \& Allred DC $1998 \mathrm{bcl}-2$ and apoptosis in lymph node positive breast carcinoma. Cancer 82 1296-1302.

Bergh J, Norberg T, Sjogren S, Lindgren A \& Holmberg L 1995 Complete sequencing of the $\mathrm{p} 53$ gene provides prognostic information in breast cancer patients, particularly in relation to adjuvant systemic therapy and radiotherapy. Nature Medicine 1 1029-1034.

Bertagna C, De Gery A, Hucher M, Fancois JP \& Zanirato J 1994 Efficacy of the combination of the nilutamide plus orchidectomy in patients with metastatic prostatic cancer. A metaanalysis of seven randomised double-blind trials (1056 patients). British Journal of Urology 73 396-402.

Bezwoda WR, Esser JD, Dansey R, Kessel I \& Lange M 1991 The value of estrogen and progesterone receptor determinations in advanced breast cancer. Estrogen receptor level but not progesterone receptor level correlates with response to tamoxifen. Cancer 68 867-872.

Bicknell R \& Harris AL 1996 Mechanisms and therapeutic implications of angiogenesis. Current Opinions in Oncology 8 60-65.

Bischoff ED, Gottardis MM, Moon TE, Heyman RA \& Lamph WW 1998 Beyond tamoxifen: the retinoid X receptorselective ligand LGD1069 (TARGRETIN) causes complete regression of mammary carcinoma. Cancer Research $\mathbf{5 8} 479$ 484.

Blamey RW 1997 The role of selective non-steroidal aromatase inhibitors in future treatment strategies. Oncology 199754 (Suppl 2) 27-31.

Blamey RW, Jonat W, Kaufmann M, Bianco AR \& Namer M 1992 Goserelin depot in the treatment of premenopausal advanced breast cancer. European Journal of Cancer 28A 810-814.

Boccardo F, Rubagotti A, Amoroso D, Mesiti M, Geraci O, Delia P, Villa E, Aldrighetti D, Genta F, De Sanctis C, Irtelli L, Donati D, Pacini P, Scotto T \& Schieppati G 1996 CMF vs tamoxifen (TAM) plus goserelin (GOS) as adjuvant treatment of ER positive (ER+) pre-perimenopausal breast cancer patients. Preliminary results of an ongoing Italian Adjuvant Breast Cancer Study (GROCTA) trial. European Journal of Cancer 32A (Suppl 2) 35 Abstract PP-5-5.

Boehm T, Folkman J, Browder T \& O’Reilly MS 1997 Antiangiogenic therapy of experimental cancer does not induce acquired drug resistance. Nature 390 404-407.

Borgstrom P, Bourdon MA, Hillan KJ, Sriramarao P \& Ferrara N 1998 Neutralizing anti-vascular endothelial growth factor antibody completely inhibits angiogenesis and growth of human prostate carcinoma micro tumors in vivo. Prostate $\mathbf{3 5}$ $1-10$.

Bruchovsky N, Goldenberg SL, Gleave M, Rennie P, Akakura K \& Sato N 1997 Intermittent therapy for prostate cancer. Endocrine-Related Cancer 4 153-177.

Brzozowski AM, Pike AC, Dauter Z, Hubbard RE, Bonn T, Engstrom O, Ohman L, Greene GL, Gustafsson JA \& Carlquist M 1997 Molecular basis of agonism and antagonism in the oestrogen receptor. Nature $\mathbf{3 8 9}$ 753-758.

Bubley GJ \& Balk SP 1996 Treatment of metastatic prostate cancer. Hematology Oncology Clinical North America 10 713-725.

Bunone G, Briand PA, Miksicek RJ \& Picard D 1996 Activation of the unliganded estrogen receptor by EGF involves the MAP kinase pathway and direct phosphorylation. EMBO Journal 15 2174-2183.

Buzdar AU, Jonat W, Howell A, Jones SE, Blomqvist C, Vogel CL, Eiermann W, Wolter JM, Steinberg M, Webster A \& Lee D for the Arimidex Study Group 1998 Anastrozole versus megestrol acetate in the treatment of postmenopausal women with advanced breast carcinoma: results of a survival update based on two mature phase III trials. Cancer 83 1142-1152.

Cairns P, Okami K, Halachmi S, Halachmi N, Esteller M, Herman JG, Jen J, Isaacs WB, Bova GS \& Sidransky D 1997 Frequent inactivation of PTEN/MMAC1 in primary prostate cancer. Cancer Research 57 4997-5000.

Cardone MH, Roy N, Stennicke HR, Salvesen GS, Franke TF, Stanbridge E, Frisch S \& Reed JC 1998 Regulation of cell death protease caspase- 9 by phosphorylation. Science $\mathbf{2 8 2}$ 1318-1321.

Castronovo V \& Belotti D 1996 TNP-470 (AGM-1470): mechanisms of action and early clinical development. European Journal of Cancer 32A 2520-2527.

Caubet J-F, Tosteson TD, Dong EW, Naylon EM, Whiting GW, Ernstoff \& Ross SD 1997 Maximum androgen blockade in advanced prostate cancer: a meta-analysis of published randomised controlled trials using nonsteroidal antiandrogens. Urology 49 71-78.

Chan JM, Stampfer MJ, Giovannucci E, Gann PH, Ma J, Wilkinson P, Hennekens CH \& Pollak M 1998 Plasma insulinlike growth factor-I and prostate cancer risk: a prospective study. Science 279 563-566.

Chin L, Pomerantz J \& DePinho RA 1998 The INK4a/ARF tumor suppressor: one gene - two products - two pathways. Trends in Biochemical Science 23 291-296.

Choudhuri R, Zhang HT, Donnini S, Ziche M \& Bicknell R 1997 An angiogenic role for the neurokines midkine and pleiotrophin in tumorigenesis. Cancer Research 57 1814-1819.

Cotter FE 1997 Antisense therapy for lymphomas. Hematology and Oncology 15 3-11.

Courjal F, Louason G, Speiser P, Katsaros D, Zeillinger R \& Theillet C 1996 Cyclin gene amplification and overexpression in breast and ovarian cancers: evidence for the selection of cyclin D1 in breast and cyclin $\mathrm{E}$ in ovarian tumors. International Journal of Cancer 69 247-253.

Culig Z, Hobisch A, Cronauer MV, Radmayr C, Trapman J, Hittmair A, Bartsch G \& Klocker H 1994 Androgen receptor activation in prostatic tumor cell lines by insulin-like growth 
factor-I, keratinocyte growth factor, and epidermal growth factor. Cancer Research 54 5474-5478.

D’Amato RJ, Loughnan MS, Flynn E \& Folkman J 1994 Thalidomide is an inhibitor of angiogenesis. Proceedings of the National Academy of Sciences of the USA 91 4082-4085.

Datta SR, Dudek H, Tao X, Masters S, Fu H, Gotoh Y \& Greenberg ME 1997 Akt phosphorylation of BAD couples survival signals to the cell-intrinsic death machinery. Cell 91 231-241.

Deng C, Zhang P, Harper JW, Elledge SJ \& Leder P 1995 Mice lacking $\mathrm{p} 21 \mathrm{CIP}$ /WAF1 undergo normal development, but are defective in G1 checkpoint control. Cell 82 675-684.

Dombernowsky P, Smith I, Falkson G, Leonard R, Panasci L, Bellmunt J, Bezwoda W, Gardin G, Gudgeon A, Morgan M, Fornasiero A, Hoffmann W, Michel J, Hatschek T, Tjabbes T, Chaudri HA, Hornberger U \& Trunet PF 1998 Letrozole, a new oral aromatase inhibitor for advanced breast cancer: double-blind randomized trial showing a dose effect and improved efficacy and tolerability compared with megestrol acetate. Journal of Clinical Oncology 16 453-461.

Dowsett M 1997 Aromatase inhibitors: current status and future applications. Endocrine-Related Cancer 4 313-321.

Dowsett M, Jacobs S, Aherne J \& Smith IE 1992 Clinical and endocrine effects of leuprorelin acetate in pre- and postmenopausal patients with advanced breast cancer. Clinical Therapeutics 14 (Suppl A) 97-103.

Dupont A, Gomez JL, Cusan L, Koutsilieris M \& Labrie F 1993 Response to flutamide withdrawal in advanced prostate cancer in progression under combination therapy. Journal of Urology 150 908-913.

Early Breast Cancer Trialists' Collaborative Group 1998 Tamoxifen for early breast cancer: an overview of the randomised trials. The Lancet 351 1451-1467.

Eckhardt SG \& Pluda JM 1997 Development of angiogenesis inhibitors for cancer therapy. Investigational New Drugs 15 1-3.

Eisenberger MA, Blumenstein BA, Crawford ED, Miller G, McLeod DG, Loehrer PJ, Wilding G, Sears K, Culkin DM, Thompson IM et al. 1998 Bilateral orchiectomy with or without flutamide for metastatic prostate cancer. New England Journal of Medicine 339 1036-1042.

El Etreby MF \& Liang Y 1998 Effect of antiprogestins and tamoxifen on growth inhibition of MCF-7 human breast cancer cells in nude mice. Breast Cancer Research and Treatment 49 109-117.

Ellis PA, Saccani-Jotti G, Clarke R, Johnston SR, Anderson E, Howell A, A'Hern R, Salter J, Detre S, Nicholson R, Robertson J, Smith IE \& Dowsett M 1997 Induction of apoptosis by tamoxifen and ICI 182,780 in primary breast cancer. International Journal of Cancer 72 608-613.

England GM \& Jordan VC 1997 Pure antiestrogens as a new therapy for breast cancer. Oncology Research 9 397-402.

Ferrer FA, Miller LJ, Andrawis RI, Kurtzman SH, Albertsen PC, Laudone VP \& Kreutzer DL 1997 Vascular endothelial growth factor (VEGF) expression in human prostate cancer: in situ and in vitro expression of VEGF by human prostate cancer cells. Journal of Urology 157 2329-2333.
Figg WD, Sartor O, Cooper MR, Thibault A, Bergan RC, Dawson N, Reed E \& Myers CE 1995 Prostate specific antigen decline following the discontinuation of flutamide in patients with stage D2 prostate cancer. American Journal of Medicine 98 412-414.

Fisher B, Constantiono JP, Wickerham DL, Redmond CK, Kavanah M, Cronin WM, Vogel VS, Robidoux A, Dimitriov N, Atkins J, Daly M, Wiend A, Tan-Chiu E, Foed L \& Wolmark N on behalf of the National Surgical Adjuvant Breast and Bowel Project 1998 Taxoxifen for prevention of breast cancer: report of the National Surgical Adjuvant Breast and Bowel Project P-1 Study. Journal of the National Cancer Institute 90 1371-1388.

FitzGerald MG, Marsh DJ, Wahrer D, Bell D, Caron S, Shannon KE, Ishioka C, Isselbacher KJ, Garber JE, Eng C \& Haber DA 1998 Germline mutations in PTEN are an infrequent cause of genetic predisposition to breast cancer. Oncogene 17 727-731.

Fleshner NE \& Trachtenberg J 1993 Treatment of advanced prostate cancer with the combination of finasteride plus flutamide: early results. European Urology 24 (Suppl 2) 106112.

Furr BJA 1989 Pharmacology of the luteinising hormonereleasing hormone (LHRH) analogue, Zoladex. Hormone Research 32 (Suppl 1) 86-92.

Furr BJA 1996 The development of Casodex (bicalutamide): preclinical studies. European Urology 29 (Suppl 2) 83-95.

Furr BJA 1997 Relative potencies of flutamide and Casodex. Endocrine-Related Cancer 4 197-202.

Gasparini G, Toi M, Verderio P, Ranieri G, Dante S, Bonoldi E, Boracchi P, Fanelli M \& Tominaga T 1998 Prognostic significance of $\mathrm{p} 53$, angiogenesis, and other conventional features in operable breast cancer: subanalysis in nodepositive and node-negative patients. International Journal of Oncology 12 1117-1125.

Gately S, Twardowski P, Stack MS, Patrick M, Boggio L, Cundiff DL, Schnaper HW, Madison L, Volpert O, Bouck N, Enghild J, Kwaan HC \& Soff GA 1996 Human prostate carcinoma cells express enyzmatic activity that converts human plasminogen to the angiogenesis inhibitor, angiostatin. Cancer Research 56 4887-4890.

Gee JM, Robertson JF, Ellis IO, Willsher P, McClelland RA, Hoyle HB, Kyme SR, Finlay P, Blamey RW \& Nicholson RI 1994 Immunocytochemical localization of Bcl-2 protein in human breast cancers and its relationship to a series of prognostic markers and response to endocrine therapy. International Journal of Cancer 59 619-628.

Geisler J, King N, Anker G, Ornati G, Di Salle E, Lonning PE \& Dowsett M 1998 In vivo inhibition of aromatization by exemestane, a novel irreversible aromatase inhibitor, in postmenopausal breast cancer patients. Clinical Cancer Research 4 2089-2093.

Geradts J \& Wilson PA 1996 High frequency of aberrant p16(INK4A) expression in human breast cancer. American Journal of Pathology 149 15-20.

Gershanovich M, Chaudri HA, Campos D, Lurie H, Bonaventura A, Jeffrey M, Buzzi F, Bodrogi I, Ludwig H, Reichardt P, O'Higgins N, Romiue G, Friederich P \& Lassus M for the Letrozole International Trial Study Group (AR/BC3) 1998 
Letrozole, a new oral aromatase inhibitor: randomized trial comparing $2.5 \mathrm{mg}$ daily, $0.5 \mathrm{mg}$ daily and aminoglutethimide in postmenopausal women with advanced breast cancer. Annals of Oncology 9 639-645.

Gillett C, Smith P, Gregory W, Richards M, Millis R, Peters G \& Barnes D 1996 Cyclin D1 and prognosis in human breast cancer. International Journal of Cancer 69 92-99.

Gillis JC \& Goa KL 1995 Tretinoin. A review of its pharmacodynamic and pharmacokinetic properties and use in the management of acute promyelocytic leukaemia. Drugs 50 897-923.

Gormley GJ, Stoner E, Bruskewitz RC, Imperato-McGinley J, Walsh PC, McConnell JD, Andriole GL, Geller J, Bracken BR, Tenover JS, Darracott VE, Frances P, Taylor A, Binkorovitz B \& Ng JSD 1992 The effect of finasteride in men with benign prostatic hyperplasia. The Finasteride Study Group. New England Journal of Medicine 327 1185-1191.

Gottardis MM, Lamph WW, Shalinsky DR, Wellstein A \& Heyman RA $1996 a$ The efficacy of 9-cis retinoic acid in experimental models of cancer. Breast Cancer Research and Treatment 38 85-96.

Gottardis MM, Bischoff ED, Shirley MA, Wagoner MA, Lamph WW \& Heyman RA $1996 b$ Chemoprevention of mammary carcinoma by LGD1069 (Targretin): an RXR-selective ligand. Cancer Research 56 5566-5570.

Green S \& Chambon P 1988 Nuclear receptors enhance our understanding of transcription regulation. Trends in Genetics 4 309-314.

Grese TA \& Dodge JA 1998 Selective estrogen receptor modulators (SERMs). Current Pharmacology Design 471-92.

Grossfeld GD, Olumi AF, Connolly JA, Chew K, Gibney J, Bhargava V, Waldman FM \& Carroll PR 1998 Locally recurrent prostate tumors following either radiation therapy or radical prostectomy have changes in Ki-67 labeling index, p53 and bcl-2 immunoreactivity. Journal of Urology 159 14371443.

Gullick WJ 1996 The c-erbB3/HER3 receptor in human cancer. Cancer Surveys 27 339-349.

Gulliford TJ, Huang GC, Ouyang X \& Epstein RJ 1997 Reduced ability of transforming growth factor-alpha to induce EGF receptor heterodimerization and downregulation suggests a mechanism of oncogenic synergy with ErbB2. Oncogene 15 2219-2223

Harper MJ \& Walpole AL 1966 Contrasting endocrine activities of cis and trans isomers in a series of substituted triphenylethylenes. Nature 21287.

Harris AL 1998 Are angiostatin and endostatin cures for cancer? The Lancet 351 1598-1599.

Harris AL, Nicholson S, Sainsbury R, Wright C \& Farndon J 1992 Epidermal growth factor receptor and other oncogenes as prognostic markers. Journal of the National Cancer Institute Monographs 11 181-187.

Harvey HA 1998 Emerging role of aromatase inhibitors in the treatment of breast cancer. Oncology 12 32-35.

Hedlund TE, Duke RC, Schleicher MS \& Miller GJ 1998 Fasmediated apoptosis in seven human prostate cancer cell lines: correlation with tumor stage. Prostate 36 92-101.
Hoffmann T, Hafner D, Ballo H, Haas I \& Bier H 1997 Antitumour activity of anti-epidermal growth factor receptor monoclonal antibodies and cis platin in ten human head and neck squamous cell carcinoma lines. Anticancer Research 17 4419-4425.

Honegger AM, Kris RM, Ullrich A \& Schlessinger J 1989 Evidence that autophosphorylation of solubilized receptors for epidermal growth factor is mediated by intermolecular cross-phosphorylation. Proceedings of the National Academy of Sciences of the USA 198986 925-929.

Houston SJ, Plunkett TA, Barnes DM, Smith P, Rubens RD \& Miles DW 1999 Overexpression of c-erbB2 is an independent marker of resistance to endocrine therapy in advanced breast cancer. British Journal of Cancer 79 1220-1226.

Howell A, DeFriend DJ, Robertson JF, Blamey RW, Anderson L, Anderson E, Sutcliffe FA \& Walton P 1996 Pharmacokinetics, pharmacological and anti-tumour effects of the specific antioestrogen ICI 182,780 in women with advanced breast cancer. British Journal of Cancer 74 300-308.

Huang A, Gandour-Edwards R, Rosenthal SA, Siders DB, Deitch AD \& White RW 1998 p53 and bcl-2 immunohistochemical alterations in prostate cancer treated with radiation therapy. Urology 51 346-351.

Huggins C \& Hodges CV 1941 Studies on prostatic cancer. I. The effect of castration of estrogen, and of androgen injection of serum phosphatase in metastatic carcinoma of the prostate. Cancer Research 1 293-297.

Iversen P, Tyrrell CJ, Kaisary AV, Anderson JB, Baert L, Tammela T, Chamberlain M, Carroll K, Gotting-Smith K \& Blackledge GR 1998 Casodex (bicalutamide) 150-mg monotherapy compared with castration in patients with previously untreated nonmetastatic prostate cancer: results from two multicenter randomized trials at a median follow-up of 4 years. Urology 51 389-396.

Jacquemier JD, Penault-Llorca FM, Bertucci F, Sun ZZ, Houvenaeghel GF, Geneix JA, Puig BD, Bardou VJ, Hassoun JA, Birnbaum D \& Viens PJ 1998 Angiogenesis as a prognostic marker in breast carcinoma with conventional adjuvant chemotherapy: a multiparametric and immunohistochemical analysis. Journal of Pathology 184 130-135.

Jarrard DF, Bova GS, Ewing CM, Pin SS, Nguyen SH, Baylin SB, Cairns P, Sidransky D, Herman JG \& Isaacs WB 1997 Deletional, mutational, and methylation analyses of CDKN2 (p16/MTS1) in primary and metastatic prostate cancer. Genes Chromosomes and Cancer 19 90-96.

Jonat W 1998 Aromatase inhibitors and their future role in postmenopausal women with early breast cancer. European Journal of Cancer 78 (Suppl 4) 5-8.

Kaisary AV, Tyrrell CJ, Peeling WB \& Griffiths K 1991 Comparison of LHRH analogue (Zoladex) with orchiectomy in patients with metastatic prostatic carcinoma. British Journal of Urology 67 502-508.

Kato S, Endoh H, Masuhiro Y, Kitamoto T, Uchiyama S, Sasaki H, Masushige S, Gotoh Y, Nishida E, Kawashima H, Metzger D \& Chambon P 1995 Activation of the estrogen receptor through phosphorylation by mitogen-activated protein kinase. Science 270 1491-1494. 
Kaufmann M 1998 LHRH analogues in early breast cancer updated status of ongoing clinical trials. British Journal of Cancer 78 (Suppl 4) 9-11.

Klijn JGM, Blamey RW, Boccardo F, Tominaga T, Jonat W, Kaufmann M, Beex L, Mauriac L, Hoctin-Boes G, Duchateau L, Sylvester R on behalf of CHAT Representatives 1998 A new standard treatment for advanced premenopausal breast cancer: a meta-analysis of the combined hormonal agent trialists' group (CHAT). European Journal of Cancer 34 (Suppl 5) S90 Abstract 405.

Klohs WD, Fry DW \& Kraker AJ 1997 Inhibitors of tyrosine kinase. Current Opinion in Oncology 9 562-568.

Klotz LH \& Newman T 1996 Does maximal androgen blockade (MAB) improve survival? A critical appraisal of the evidence. Canadian Journal of Urology 3 246-250.

Krajewski S, Blomqvist C, Franssila K, Krajewska M, Wasenius VM, Niskanen E, Nordling S \& Reed JC 1995 Reduced expression of proapoptotic gene BAX is associated with poor response rates to combination chemotherapy and shorter survival in women with metastatic breast adenocarcinoma. Cancer Research 55 4471-4478.

Kroemer G, Dallaporta B \& Resche-Rigon M 1998 The mitochondrial death/life regulator in apoptosis and necrosis. Annual Review of Physiology 60 619-642.

Labrie F, Belanger A, Simard J, Labrie C \& Dupont A 1993 Combination therapy for prostate cancer. Endocrine and biologic basis of its choice as new standard first-line therapy. Cancer 71 (Suppl) 1059-1067.

Lamb JC, English H, Levandoski PL, Rhodes GR, Johnson RK \& Isaacs JT 1992 Prostatic involution in rats induced by a novel 5 alpha-reductase inhibitor, SK\&F 105,657: role for testosterone in the androgenic response. Endocrinology 130 685-694.

Lane DP \& Hall PA 1997 MDM2-arbiter of p53's destruction. Trends in Biochemical Science 22 372-374.

Lee AV, Hilsenbeck SG \& Yee D 1998 IGF system components as prognostic markers in breast cancer. Breast Cancer Research and Treatment 47 295-302.

Leone G, DeGregori J, Sears R, Jakoi L \& Nevins JR 1997 Myc and Ras collaborate in inducing accumulation of active cyclin E/Cdk2 and E2F. Nature 387 422-426.

Levenson AS \& Jordan VC 1998 The key to the antiestrogenic mechanism of raloxifene is amino acid 351 (aspartate) in the estrogen receptor. Cancer Research 58 1872-1875.

Li PK, Chu GH, Guo JP, Peters A \& Selcer KW 1998 Development of potent non-estrogenic estrone sulfatase inhibitors. Steroids 63 425-432.

Liebertz G, Kelly WK, Theodoulou M, Liebertz C, Kelly WK, Theodoulou M, Curley T, Dean L, Mazumdar M, Vlamis V \& Scher HI 1995 High dose Casodex for prostate cancer (PC): PSA declines in patients (pts) with flutamide withdrawal responses. Proceedings of the American Society of Clinical Oncology 14232.

Loda M, Cukor B, Tam SW, Lavin P, Fiorentino M, Draetta GF, Jessup JM \& Pagano M 1997 Increased proteosomedependent degradation of the cyclin-dependent kinase inhibitor p27 in aggressive colorectal carcinomas. Nature Medicine 3 231-234.
Lønning PE 1998 Aromatase inhibitors and their future role in postmenopausal women with early breast cancer. British Journal of Cancer 78 (Suppl 4) 12-15.

Lønning PE, Geisler J, Johannessen DC \& Ekse D 1997 Plasma estrogen suppression with aromatase inhibitors evaluated by a novel, sensitive assay for estrone sulphate. Journal of Steroid Biochemistry and Molecular Biology 61 255-260.

Lowe SW, Schmitt EM, Smith SW, Osborne BA \& Jacks T 1993 $\mathrm{p} 53$ is required for radiation-induced apoptosis in mouse thymocytes. Nature 29 847-849.

Luo S, Martel C, LeBlanc G, Candas B, Singh SM, Labrie C, Simard J, Bélanger A \& Labrie F 1996 Relative potencies of Flutamide and Casodex: preclinical studies. EndocrineRelated Cancer 3 229-241.

Lydon NB, Mett H, Mueller M, Becker M, Cozens RM, Stover D, Daniels D, Traxler P \& Buchdunger E 1998 A potent protein-tyrosine kinase inhibitor which selectively blocks proliferation of epidermal growth factor receptor-expressing tumor cells in vitro and in vivo. International Journal of Cancer 76 154-163.

McDonnell TJ, Troncoso P, Brisbay SM, Logothetis C, Chung LW, Hsieh JT, Tu SM \& Campbell ML 1992 Expression of the protooncogene bcl-2 in the prostate and its association with emergence of androgen-independent prostate cancer. Cancer Research 52 6940-6944.

MacGrogan D, Pegram M, Slamon D \& Bookstein R 1997 Comparative mutational analysis of DPC4 (Smad4) in prostatic and colorectal carcinomas. Oncogene 15 1111-1114.

McGuire WL 1978 Steroid receptors in human breast cancer. Cancer Research 38 4289-4291.

McIlwrath AJ, Vasey PA, Ross GM \& Brown R 1994 Cell cycle arrests and radiosensitivity of human tumor cell lines: dependence on wild-type p53 for radiosensitivity. Cancer Research 54 3718-3722.

McInerney EM, Weis KE, Sun J, Mosselman S \& Katzenellenbogen BS 1998 Transcription activation by the human estrogen receptor subtype beta (ER beta) studied with ER beta and ER alpha receptor chimeras. Endocrinology 139 4513-4522.

Maehama T \& Dixon JE 1998 The tumor suppressor, PTEN/ MMAC1, dephosphorylates the lipid second messenger, phosphatidylinositol 3,4,5-trisphosphate. Journal of Biological Chemistry 273 13375-13378.

Mangelsdorf DJ, Kliewer SA, Kakizuka A, Umesono K \& Evans RM 1993 Retinoid receptors. Recent Progress in Hormone Research 48 99-121.

Marsh KL \& Varley JM 1998 Frequent alterations of cell cycle regulators in early-stage breast lesions as detected by immunohistochemistry. British Journal of Cancer 77 14601468.

Marshall E 1998 The power of the front page of The New York Times. Science 280 996-997.

Matsushima H, Kitamura T, Goto T, Hosaka Y, Homma Y \& Kawabe K 1997 Combined analysis with Bcl-2 and p53 immunostaining predicts poorer prognosis in prostatic carcinoma. Journal of Urology 158 2278-2283.

Menon M, Glode M, Martin K, McLeod D, Cohen S, Steadman B, Molineaux C, Gefter ML, Kuca B \& Garnick MB 1998 
Abarelix (PPI-149), a novel and potent GnRH antagonist, induces a rapid and profound reduction in testosterone and PSA in advanced prostate cancer patients (PcCa). Journal of Urology 159334 Abstract 1285.

Millauer B, Longhi MP, Plate KH, Shawver LK, Risau W, Ullrich A \& Strawn LM 1996 Dominant-negative inhibition of Flk-1 suppresses the growth of many tumor types in vivo. Cancer Research 56 1615-1620.

Miller VA, Benedetti FM, Rigas JR, Verret AL, Pfister DG, Straus D, Kris MG, Crisp M, Heyman R, Loewen GR, Truglia JA \& Warrell RP Jr 1997 Initial clinical trial of a selective retinoid X receptor ligand, LGD1069. Journal of Clinical Oncology 15 790-795.

Miyashita T, Krajewski S, Krajewska M, Wang HG, Lin HK, Liebermann DA, Hoffman B \& Reed JC 1994 Tumor suppressor $\mathrm{p} 53$ is a regulator of bcl-2 and bax gene expression in vitro and in vivo. Oncogene 9 1799-1805.

Modjtahedi H, Hickish T, Nicolson M, Moore J, Styles J, Eccles S, Jackson E, Salter J, Sloane J, Spencer L, Priest K, Smith I, Dean C \& Gore M 1996 Phase I trial and tumour localisation of the anti-EGFR monoclonal antibody ICR62 in head and neck or lung cancer. British Journal of Cancer 73 228-235.

Montironi R, Pmante R, Diamanti L \& Magi-Galluzzi C 1998 Apoptosis in prostatic adenocarcinoma following complete androgen ablation. Urology International 60 (Suppl 1) 25-29.

Moran MF, Koch CA, Anderson D, Ellis C, England L, Martin GS \& Pawson T 1990 Src homology region 2 domains direct protein-protein interactions in signal transduction.

Proceedings of the National Academy of Sciences of the USA 87 8622-8626.

Moyer JD, Barbacci EG, Iwata KK, Arnold L, Boman B, Cunningham A, DiOrio C, Doty J, Morin J, Moyer MP, Neveu M, Pollack VA, Pustilnik LR, Reynolds MM, Sloan D, Theleman A \& Miller P 1997 Induction of apoptosis and cell cycle arrest by CP-358,774, an inhibitor of epidermal growth factor receptor tyrosine kinase. Cancer Research 57 48384848.

Muller D, Bouchard C, Rudolph B, Steiner P, Stuckmann I, Saffrich R, Ansorge W, Huttner W \& Eilers M 1997 Cdk2dependent phosphorylation of p27 facilitates its Myc-induced release from cyclin E/cdk2 complexes. Oncogene 15 25612576.

Muller WJ, Arteaga CL, Muthuswamy SK, Siegel PM, Webster MA, Cardiff RD, Meise KS, Li F, Halter SA \& Coffey RJ 1996 Synergistic interaction of the Neu proto-oncogene product and transforming growth factor alpha in the mammary epithelium of transgenic mice. Molecular and Cellular Biology 165726 5736.

Musgrove EA, Hamilton JA, Lee CSL, Sweeney KJE, Watts CKW \& Sutherland RL 1993 Growth factor, steroid and steroid antagonist regulation of cyclin gene expression associated with changes in T-47D human breast cancer cell cycle progression. Molecular and Cellular Biology 133577 3587.

Musgrove EA, Sarcevic B \& Sutherland RL 1996 Inducible expression of cyclin D1 in T-47-D human breast cancer cells is sufficient for CDK2 activation and pRB hyperphosphorylation. Journal of Cellular Biochemistry 60 363-378.
Nieh PT 1995 Withdrawal phenomenon with the antiandrogen casodex. Journal of Urology 153 1070-1073.

Neuman E, Ladha MH, Lin N, Upton TM, Miller SJ, DiRenzo J, Pestell RG, Hinds PW, Dowdy SF, Brown M \& Ewen ME 1997 Cyclin D1 stimulation of estrogen receptor transcriptional activity independent of cdk4. Molecular and Cellular Biology 17 5338-5347.

Ogilvie DJ, Wedge SR, Dukes M, Kendrew J, Curwen JO, Thomas AP, Hennequin LF, Ple P, Stokes ESE, Johnstone C, Wadsworth P, Richmond GHP \& Curry B 1999 ZD1490: an orally administered inhibitor of VEGF signalling with panxenograft anti-tumor activity. Proceedings of the American Association for Cancer Research $\mathbf{4 0} 69$.

O’Reilly MS, Holmgren L, Shing Y, Chen C, Rosenthal RA, Moses M, Lane WS, Cao Y, Sage EH \& Folkman J 1994 Angiostatin: a novel angiogenesis inhibitor that mediates the suppression of metastasis by a Lewis lung carcinoma. Cell 79 315-328.

O’Reilly MS, Holmgren L, Chen C \& Folkman J 1996 Angiostatin induces and sustains dormancy of human primary tumors in mice. Nature Medicine 2 689-692.

Ornstein DK, Rao GS, Johnson B, Charlton ET \& Andriole GL 1996 Combined finasteride and flutamide therapy in men with advanced prostate cancer. Urology 48 901-905.

Owen-Schaub LB, Zhang W, Cusack JC, Angelo LS, Santee SM, Fujiwara T, Roth JA, Deisseroth AB, Zhang WW \& Kruzel E 1995 Wild-type human p53 and a temperature-sensitive mutant induce Fas/APO-1 expression. Molecular and Cellular Biology 15 3032-3040.

Pacilio C, Germano D, Addeo R, Altucci L, Petrizzi VB, Cancemi M, Cicatiello L, Salzano S, Lallemand F, Michalides RJ, Bresciani F \& Weisz A 1998 Constitutive overexpression of cyclin D1 does not prevent inhibition of hormoneresponsive human breast cancer cell growth by antiestrogens. Cancer Research 58 871-876.

Pan G, Ni J, Wei YF, Yu G, Gentz R \& Dixit VM 1997 An antagonist decoy receptor and a death domain-containing receptor for TRAIL. Science 277 815-818.

Pasqualini JR, Cortes-Prieto J, Chetrite G, Talbi M \& Ruiz A 1997 Concentrations of estrone, estradiol and their sulfates, and evaluation of sulfatase and aromatase activities in patients with breast fibroadenoma. International Journal of Cancer $\mathbf{7 0}$ 639-643.

Pasqualini JR, Paris J, Sitruk-Ware R, Chetrite G \& Botella J 1998 Progestins and breast cancer. Journal of Steroid Biochemistry and Molecular Biology 65 225-235.

Perrault D, Eisenhauer EA, Pritchard KI, Panasci L, Norris B, Vandenberg T \& Fisher B 1996 Phase II study of the progesterone antagonist mifepristone in patients with untreated metastatic breast carcinoma: a National Cancer Institute of Canada Clinical Trials Group study. Journal of Clinical Oncology 14 2709-2712.

Peterziel H, Culig Z, Stober J, Hobisch A, Radmayr C, Bartsch G, Klocker H \& Cato AC 1995 Mutant androgen receptors in prostatic tumors distinguish between amino-acid-sequence requirements for transactivation and ligand binding. International Journal of Cancer 63 544-550. 
Phillips P 1998 Cancer experts offer healthy dose of skepticism toward hype over antiangiogenesis agents. Journal of the American Medical Association 279 1936-1937.

Pienta KJ, Esper PS, Zwas F, Krzeminski R \& Flaherty LE 1997 Phase II chemoprevention trial of oral fenretinide in patients at risk for adenocarcinoma of the prostate. American Journal of Clinical Oncology 20 36-39.

Planas-Silva MD \& Weinberg RA 1997 Estrogen-dependent cyclin E-cdk2 activation through p21 redistribution. Molecular and Cellular Biology 17 4059-4069.

Porter PL, Malone KE, Heagerty PJ, Alexander GM, Gatti LA, Firpo EJ, Daling JR \& Roberts JM 1997 Expression of cellcycle regulators $\mathrm{p} 27 \mathrm{Kip} 1$ and cyclin $\mathrm{E}$, alone and in combination, correlate with survival in young breast cancer patients. Nature Medicine 3 222-225.

Powles T, Eeles R, Ashley S, Easton D, Chang J, Dowsett M, Tidy A, Viggers J \& Davey J 1998 Interim analysis of the incidence of breast cancer in the Royal Marsden Hospital tamoxifen randomised chemoprevention trial. The Lancet $\mathbf{3 5 2}$ 98-101.

Presti JC Jr, Fair WR, Andriole G, Sogani PC, Seidmon EJ, Ferguson D, Ng J \& Gormley GJ 1992 Multicenter, randomized, double-blind, placebo controlled study to investigate the effect of finasteride (MK-906) on stage D prostate cancer. Journal of Urology 148 1201-1204.

Prostate Cancer Trialists' Collaborative Group 1995 Maximum androgen blockade in advanced prostate cancer: an overview of 22 randomised trials with 3283 deaths in 5710 patients. The Lancet 346 265-269.

Reed JC 1997 Double identity for proteins of the Bcl-1 family. Nature 387 773-776.

Reissmann T, Felberbaum R, Diedrich K, Engel J, ComaruSchally AM, Schally AV 1995 Development and application of luteinizing hormone-releasing hormone antagonists in the treatment of infertility: an overview. Human Reproduction $\mathbf{1 0}$ 1974-1981.

Relf M, LeJeune S, Scott PA, Fox S, Smith K, Leek R, Moghaddam A, Whitehouse R, Bicknell R \& Harris AL 1997 Expression of the angiogenic factors vascular endothelial cell growth factor, acidic and basic fibroblast growth factor, tumor growth factor beta-1, platelet-derived endothelial cell growth factor, placenta growth factor, and pleiotrophin in human primary breast cancer and its relation to angiogenesis. Cancer Research 57 963-969.

Reynisdottir I, Polyak K, Iavarone A \& Massague J 1995 Kip/Cip and Ink4 Cdk inhibitors cooperate to induce cell cycle arrest in response to TGF-beta. Genes and Development $91831-$ 1845.

Rizvi NA, Marshall JL, Ness E, Yoe J, Gill GM, Truglia JA, Loewen GR, Jaunakais D, Ulm EH \& Hawkins MJ $1998 a$ Phase I study of 9-cis-retinoic acid (ALRT1057 capsules) in adults with advanced cancer. Clinical Cancer Research 4 1437-1442.

Rizvi NA, Ness E, Dahut W, Marshall J, Parker BA, Amyotte S, Cato A, Matsumoto R \& Hawkins MJ 1998b A phase 1-2 trial of LGD 1550, a novel RAR-selective retinoid, in advanced cancer patients. Proceedings of the American Society of Clinical Oncology 17 Abstract 828.
Robertson JFR, Willscher PC, Winterbottom L, Blamey RW \& Thorpe S 1999 Onapristone, a progesterone receptor antagonist, as first-line therapy in primary breast cancer. European Journal of Cancer 35 214-218.

Roux-Dosseto M, Romain S, Dussault N, Desideri C, Piana L, Bonnier P, Tubiana N \& Martin PM 1992 c-Myc gene amplification in selected node-negative breast cancer patients correlates with high rate of early relapse. European Journal of Cancer 28A 1600-1604.

Rutqvist LE 1998 Controversial issues in adjuvant systemic therapy of early breast cancer. Acta Oncologica 37 421-430.

Said TK, Conneely OM, Medina D, O'Malley BW \& Lydon JP 1997 Progesterone, in addition to estrogen, induces cyclin D1 expression in the murine mammary epithelial cell in vivo. Endocrinology 138 3933-3939.

Santen RJ, Leszczynski D, Tilson-Mallet N, Feil PD, Wright C, Manni A \& Santner SJ 1986 Enzymatic control of estrogen production in human breast cancer: relative significance of aromatase versus sulfatase pathways. Annals of the New York Academy of Sciences 464 126-137.

Santen RJ, Santner SJ, Pauley RJ, Tait L, Kaseta J, Demers LM, Hamilton C, Yue W \& Wang JP 1997 Estrogen production via the aromatase enzyme in breast carcinoma: which cell type is responsible? Journal of Steroid Biochemistry and Molecular Biology 61 267-271.

Sarosdy MF, Schellhammer PF, Sharifi R, Block NL, Soloway MS, Venner PM, Patterson AL, Vogelzang NJ, Chodak GW, Klein EA, Schellenger JJ \& Kolvenbag GJ 1998 Comparison of goserelin and leuprolide in combined androgen blockade therapy. Urology 52 82-88.

Sartor O, Cooper M, Weinberger M, Headlee D, Thibault A, Tompkins A, Steinberg S, Figg WD, Linehan WM \& Myers CE 1994 Surprising activity of flutamide withdrawal, when combined with aminoglutethimide, in treatment of 'hormonerefractory' prostate cancer. Journal of the National Cancer Institute 86 222-227.

Schally AV \& Comaru-Schally M 1997 Rational use of agonists and antagonists of LHRH in the treatment of hormonesensitive neoplasms and gynaecologic conditions. Advances in Drug Delivery Reviews 28 157-169.

Schellhammer PF, Sharifi R, Block NL, Soloway MS, Venner PM, Patterson AL, Sarosdy MF, Vogelzang NJ, Schellenger JJ \& Kolvenbag GJ 1997a Clinical benefits of bicalutamide compared with flutamide in combined androgen blockade for patients with advanced prostatic carcinoma: final report of a double-blind, randomized, multicenter trial. Casodex Combination Study Group. Urology 50 330-336.

Schellhammer PF, Venner P, Haas GP, Small EJ, Nieh PT, Seabaugh DR, Patterson AL, Klein E, Wajsman Z, Furr B, Chen Y \& Kolvenbag GJCM. $1997 b$ Prostate specific antigen decreases after withdrawal of antiandrogen therapy with bicalutamide or flutamide in patients receiving combined androgen blockade. Journal of Urology 157 1731-1735.

Scher HI \& Kelly 1993 Flutamide withdrawal syndrome: its impact on clinical trials in hormone-refractory prostate cancer. Journal of Clinical Oncology 11 1566-1572.

Schmidt F, Sundaram K, Thau RB \& Bardin CW 1984 [1-Ac-DNal(2)1, 2-4FD-Phe, 3-D-Trp, 6-D-Arg] LHRH, a potent 
antagonist of LHRH, produces a transient edema and behavioural changes in rats. Contraception 29 283-289.

Schutte M, Hruban RH, Hedrick L, Cho KR, Nadasdy GM, Weinstein CL, Bova GS, Isaacs WB, Cairns P, Nawroz H, Sidransky D, Casero RA Jr, Meltzer PS, Hahn SA \& Kern SE 1996 DPC4 gene in various tumor types. Cancer Research 56 2527-2530.

Sedlacek HH, Czech J, Naik R, Kaur G, Worland P, Losiewicz M, Parker B, Carlson B, Smith A, Senderowicz A \& Sausville E 1996 Flavopiridol (L86 8275; NSC 649890) a new kinase inhibitor for tumour therapy. International Journal of Oncology 9 1143-1168.

Seymour L \& Bezwoda WR 1994 Positive immunostaining for platelet derived growth factor (PDGF) is an adverse prognostic factor in patients with advanced breast cancer. Breast Cancer Research and Treatment 32 229-233.

Shalinsky DR, Bischoff ED, Lamph WW, Zhang L, Boehm MF, Davies PJ, Nadzan AM \& Heyman RA 1997 A novel retinoic acid receptor-selective retinoid, ALRT1550, has potent antitumor activity against human oral squamous carcinoma xenografts in nude mice. Cancer Research 57 162-168.

Sharief Y, Wilson EM \& Hall SH 1995 Androgen receptor gene mutations associated with prostatic carcinoma. Proceedings of the American Association for Cancer Research 361605.

Shepherd PR, Withers DJ \& Siddle K 1998 Phosphoinositide 3kinase: the key switch mechanism in insulin signalling. Biochemical Journal 333 471-490.

Sherr CJ 1996 Cancer cell cycles. Science 274 1672-1677.

Sherwood ER \& Lee C 1995 Epidermal growth factor-related peptides and the epidermal growth factor receptor in normal and malignant prostate. World Journal of Urology 13 290-296.

Sicinski P, Donaher JL, Parker SB, Li T, Fazeli A, Gardner H, Haslam SZ, Bronson RT, Elledge SJ \& Weinberg RA 1995 Cyclin D1 provides a link between development and oncogenesis in the retina and the breast. Cell 82 621-630.

Slamon DJ, Godolphin W, Jones LA, Holt JA, Wong SG, Keith DE, Levin WJ, Stuart SG, Udove J, Ullrich A \& Press MF 1989 Studies of the HER-2/neu proto-oncogene in human breast and ovarian cancer. Science 244 707-712.

Slamon D, Leyland-Jones B, Shak S, Paton V, Bajamonde A, Fleming T, Eiermann W, Wolter J, Baselga J \& Norton L 1998 Addition of Herceptin (humanized anti-HER2 antibody) to first line chemotherapy for HER2 overexpressing metastatic breast cancer (HER2+/MBC) markedly increases anticancer activity: a randomized, multinational controlled phase III trial. Proceedings of the American Society of Clinical Oncology 17 Abstract 377.

Small EJ \& Carroll PR 1994 Prostate-specific antigen decline after casodex withdrawal: evidence for an antiandrogen withdrawal syndrome. Urology 43 408-410.

Small EJ \& Srinivas S 1995 The antiandrogen withdrawal syndrome. Experience in a large cohort of unselected patients with advanced prostate cancer. Cancer 76 1428-1434.

Stapleton AM, Zbell P, Kattan MW, Yang G, Wheeler TM, Scardino PT \& Thompson TC 1998 Assessment of the biologic markers p53, Ki-67 and apoptotic index as predictive indicators of prostate carcinoma recurrence after surgery. Cancer 82 168-175.
Stattin P, Damber JE, Karlberg L, Nordgren H \& Bergh A 1996 $\mathrm{Bcl}-2$ immunoreactivity in prostate tumorigenesis in relation to prostatic intraepithelial neoplasia, grade, hormonal status, metastatic growth and survival. Urology Research 24 257264.

Strawn LM, McMahon G, App H, Schreck R, Kuchler WR, Longhi MP, Hui TH, Tang C, Levitzki A, Gazit A, Chen I, Keri G, Orfi L, Risau W, Flamme I, Ullrich A, Hirth KP \& Shawver LK 1996 Flk-1 as a target for tumor growth inhibition. Cancer Research 56 3540-3545.

Sweiki D, Itin A, Soffer D \& Keshet E 1992 Vascular endothelial growth factor induced by hypoxia may mediate hypoxiainitiated angiogenesis. Nature 359 843-845.

Taylor CW, Green S, Dalton WS, Martino S, Rector D, Ingle JN, Robert NJ, Budd GT, Paradelo JC, Natale RB, Bearden JD, Mailliard JA \& Osborne CK 1998 Multicenter randomized clinical trial of goserelin versus surgical ovariectomy in premenopausal patients with receptor-positive metastatic breast cancer: an intergroup study. Journal of Clinical Oncology 16 994-999.

Teixeira C, Reed JC \& Pratt MA 1995 Estrogen promotes chemotherapeutic drug resistance by a mechanism involving Bcl-2 proto-oncogene expression in human breast cancer cells. Cancer Research 55 3902-3907.

Tremblay MR \& Poirier D 1998 Overview of a rational approach to design type I $17 \beta$-hydroxysteroid dehydrogenase inhibitors without estrogenic activity: chemical synthesis and biological evaluation. Journal of Steroid Biochemistry and Molecular Biology 66 179-191.

Tsihlias J, Kapusta LR, DeBoer G, Morava-Protzner I, Zbieranowski I, Bhattacharya N, Catzavelos GC, Klotz LH \& Slingerland JM 1998 Loss of cyclin-dependent kinase inhibitor p27Kip1 is a novel prognostic factor in localized human prostate adenocarcinoma. Cancer Research 58 542548.

Van Look PF \& Hertzen H 1995 Clinical uses of antiprogestogens. Human Reproduction Update 1 19-34.

Varley JM, Swallow JE, Brammar WJ, Whittaker JL \& Walker RA 1987 Alterations to either c-erbB-2(neu) or c-myc protooncogenes in breast carcinomas correlate with poor short-term prognosis. Oncogene 1 423-430.

Veldscholte J, Berrevoets CA, Ris-Stalpers C, Kuiper GG, Jenster G, Trapman J, Brinkmann AO \& Mulder E 1992 The androgen receptor in $\mathrm{LNCaP}$ cells contains a mutation in the ligand binding domain which affects steroid binding characteristics and response to antiandrogens. Journal of Steroid Biochemistry and Molecular Biology 41 665-669.

Veronesi U, Maisonneuve P, Costa A, Sacchini V, Maltoni C, Robertson C, Rotmensz N \& Boyle P 1998 Prevention of breast cancer with tamoxifen: preliminary findings from the Italian randomised trial among hysterectomised women. Italian Tamoxifen Prevention Study. The Lancet 352 93-97.

Vlahos CJ, Kriauciunas TD, Gleason PE, Jones JA, Eble JN, Salvas D, Falcone JF \& Hirsch KS 1993 Platelet-derived growth factor induces proliferation of hyperplastic human prostatic stromal cells. Journal of Cellular Biochemistry 52 404-413. 
Vogelzang NJ, Chodak GW, Soloway MS, Block NL, Schellhammer PF, Smith JA, Caplan RJ, Kennealey GT for the Zoladex Prostate Study Group 1995 Goserelin versus orchidectomy in the treatment of advanced prostate cancer: final results of a randomised trial. Urology 46 220-226.

Wagner BL, Pollio G, Giangrande P, Webster JC, Breslin M, Mais DE, Cook CE, Vedeckis WV, Cidlowski JA \& McDonnell DP 1999 The novel progesterone receptor antagonists RTI 3021012 and RTI 3021-022 exhibit complex glucocorticoid receptor antagonist activities: implications for the development of dissociated antiprogestins. Endocrinology 140 14491458 .

Wamil BD, Thurman GB, Sundell HW, DeVore RF, Wakefield G, Johnson DH, Wang YF \& Hellerqvist CG 1997 Soluble Eselectin in cancer patients as a marker of the therapeutic efficacy of CM101, a tumor-inhibiting anti-neovascularization agent, evaluated in phase I clinical trial. Journal of Cancer Research and Clinical Oncology 123 173-179.

Wang TC, Cardiff RD, Zukerberg L, Lees E, Arnold A \& Schmidt EV 1994 Mammary hyperplasia and carcinoma in MMTV-cyclin D1 transgenic mice. Nature 369 669-671.

Watts CK, Brady A, Sarcevic B, deFazio A, Musgrove EA \& Sutherland RL 1995 Antioestrogen inhibition of cell cycle progression in breast cancer cells is associated with inhibition of cyclin dependent kinase activity and decreased retinoblastoma protein phosphorylation. Molecular Endocrinology 9 1804-1813.

Waxman J, Man A, Hendry WF, Whitfield HN, Besser GM, Tiptaft RC, Paris AM \& Oliver RT 1985 Importance of early tumour exacerbation in patients treated with long acting analogues of gonadotrophin releasing hormone for advanced prostatic cancer. British Medical Journal 291 1387-1388.
Weidner N 1998 Tumoural vascularity as a prognostic factor in cancer patients: the evidence continues to grow. Journal of Pathology 184 119-122.

Weidner N, Carroll PR, Flax J, Blumenfeld W \& Folkman J 1993 Tumour angiogenesis correlates with metastasis in invasive prostate carcinoma. American Journal of Pathology 143 401409.

Weinbauer GF \& Nieschlag E 1992 LH-RH antagonists: state of the art and future perspectives. Recent Results in Cancer Research 124 113-136.

Whang YE, Wu X, Suzuki H, Reiter RE, Tran C, Vessella RL, Said JW, Isaacs WB \& Sawyers CL 1998 Inactivation of the tumor suppressor PTEN/MMAC1 in advanced human prostate cancer through loss of expression. Proceedings of the National Academy of Sciences of the USA 95 5246-5250.

White R \& Parker MG 1998 Molecular mechanisms of steroid hormone action. Endocrine-Related Cancer 5 1-14.

Woodburn JR, Barker AJ, Gibson KH, Ashton SE, Wakeling AE, Curry BJ, Scarlett L \& Henthorn LR 1997 ZD1839, an epidermal growth factor tyrosine kinase inhibitor selected for clinical development. Proceedings of the American Association for Cancer Research 38 Abstract 4251.

Xu X, Williams JW, Gong H, Finnegan A \& Chong AS 1996 Two activities of the immunosuppressive metabolite of leflunomide, A77 1726. Inhibition of pyrimidine nucleotide synthesis and protein tyrosine phosphorylation. Biochemical Pharmacology 52 527-534.

Yang NN, Venugopalan M, Hardikar S \& Glasebrook A 1996 Identification of an estrogen response element activated by metabolites of $17 \beta$-estradiol and raloxifene. Science $\mathbf{2 7 3}$ 1222-1225.

Zwijsen RM, Wientjens E, Klompmaker R, van der Sman J, Bernards R \& Michalides RJ 1997 CDK-independent activation of estrogen receptor by cyclin D1. Cell 88 405-415. 